\title{
Deep drilling at Vostok station, Antarctica: history and recent events
}

\author{
N.I. VASILIEV, ${ }^{1}$ P.G. TALALAY, ${ }^{1}$ N.E. BOBIN, ${ }^{1}$ V.K. CHISTYAKOV, ${ }^{1}$ V.M. ZUBKOV, ${ }^{1}$ \\ A.V. KRASILEV, ${ }^{1 \dagger}$ A.N. DMITRIEV, ${ }^{1}$ S.V. YANKILEVICH, ${ }^{1}$ V.Ya. LIPENKOV ${ }^{2}$ \\ ${ }^{1}$ St. Petersburg Mining Institute, 21 Line, 2, 199026 St Petersburg, Russia \\ E-mail: talalay@PT15797.spb.edu \\ ${ }^{2}$ Arctic and Antarctic Research Institute, 38 Beringa Street, 199397 St Petersburg, Russia
}

\begin{abstract}
Deep drilling into the ice sheet at Vostok station, Antarctica, was started by specialists of the Leningrad Mining Institute (since 1991, St Petersburg State Mining Institute) in 1970. Five deep holes were cored: hole No. 1 to $952 \mathrm{~m}$; hole No. 2 to $450.4 \mathrm{~m}$; hole No. 3G (3G-1, 3G-2) to $2201.7 \mathrm{~m}$; hole No. 4G (4G-1, 4G-2) to 2546.4 m; and hole No. 5G (5G-1) to 3650.2 $\mathrm{m}$ depth. Drilling of hole 5G-1 is not yet complete. The deep drilling at Vostok station has had successes and problems. All the deep holes at Vostok have undergone at least one offset drilling operation because of problems with lost drills. These deviations were made successfully using a thermal drilling technique. Several drilling records have been achieved at Vostok station. The deepest dry hole, No. $1(952 \mathrm{~m})$, was made during Soviet Antarctic Expedition (SAE) 17 in 1972. The deepest fluid-filled hole, No. 5G-1, made by a thermal drill (TBZS132), reached $2755 \mathrm{~m}$ during SAE 38 in 1993. The deepest fluid-filled hole in ice, No. 5G-1, was drilled with a KEMS-132 electromechanical drill and was stopped above Vostok Subglacial Lake at $3650.2 \mathrm{~m}$ depth during Russian Antarctic Expedition (RAE) 51 in 2006.
\end{abstract}

\section{INTRODUCTION}

On 16 December 1957, during the International Geophysical Year (1957/58), Vostok station $\left(78^{\circ} 28^{\prime} \mathrm{S}, 106^{\circ} 48^{\prime} \mathrm{E}\right.$; $3488 \mathrm{~m}$ a.s.I.) was established near the South Geomagnetic Pole, the point where the Earth's magnetic dipole axis crosses the Earth's surface (Fig. 1). The South Geomagnetic Pole, like the South Magnetic Pole, changes through time, although more slowly. For example, in mid-1996 the South Geomagnetic Pole was situated at $79^{\circ} 18^{\prime} \mathrm{S}, 108^{\circ} 30^{\prime} \mathrm{E}$, approximately $100 \mathrm{~km}$ from Vostok. Since 1957, Vostok has existed as a year-round research base of the Complex Antarctic Expedition (CAE). In 1959 CAE was renamed the Soviet Antarctic Expedition (SAE). After the collapse of the USSR, the Russian Federation assumed obligations relating to the Antarctic Treaty, and on 7 August 1992, according to Edict No. 824 of the President of the Russian Federation, SAE became the Russian Antarctic Expedition (RAE).

The first ice-drilling experience took place at Vostok in 1958, when wintering-over personnel received a message from the 4th CAE to start drilling into the ice sheet. Nine thermal-drill types were designed from makeshift material and equipment found at the station. All of them were finally frozen in the ice. Nevertheless, four boreholes were drilled to a maximum depth of $52 \mathrm{~m}$ (Fig. 2).

In 1963, a research agreement between the Arctic and Antarctic Research Institute (AARI) and two Moscow research institutes - the Moscow Mining Institute and the Moscow Institute of Radio-electronics and Mining Electromechanics - led to the design of a thermal ice-drilling system. In 1967 a collaboration between AARI and the Leningrad Mining Institute (LMI) led to development of the thermal coring drill for drilling in dry holes. Later, further improvements were made under a new cooperative venture between AARI and LMI.
During the winter of 1969 (14th SAE) two test holes were drilled near Mirny station and a $250 \mathrm{~m}$ deep hole was drilled in 36 days at the $50 \mathrm{~km}$ mark of the Mirny-Vostok traverse. In 1970, 12 years after the first experience, drilling at Vostok station was conducted by LMI specialists. (In 1991 LMI was renamed the St Petersburg State Mining Institute (SPSMI)). Since 1970, five deep holes have been cored: hole No. 1 to 952 m; hole No. 2 to 450.4 m; hole No. 3G (3G-1, 3G-2) to $2201.7 \mathrm{~m}$; hole No. 4G (4G-1, 4G-2) to $2546.4 \mathrm{~m}$; and hole No. 5G (5G-1) to $3650.2 \mathrm{~m}$ depth.

In the mid-1990s, the existence of a large subglacial lake beneath the Antarctic ice sheet (since named Vostok Subglacial Lake - its south part underlies the station) was recognized (Ridley and others, 1993). Previously, the primary objective of deep ice-core drilling at Vostok was to acquire englacial geophysical data and a long ice core for studies of past climate history. Now, the primary interest is to study the lake properties using the existing hole No. 5G-1.

In this paper, we recollect our successes and problems including the reasons for accidents, some of which have not previously been published. Even for those that have been published, descriptions of drilling operations have mostly been in Russian and not available for the English-reading scientific community. Most of the photographs are published here for the first time. The last part of the paper is devoted to our plans for penetrating and sampling Vostok Subglacial Lake.

\section{DRILLING OPERATIONS IN HOLE NO. 1 (1970-73)} 15th SAE (1970)

In the summer season of the 15th SAE, the first drilling shelter was constructed on two steel sleds (Fig. 3), providing a work area measuring $15 \times 2.9 \times 2.5 \mathrm{~m}$. A $9.7 \mathrm{~m}$ round tower, measured from the top of the hole, was constructed in the center of the work area and wrapped in rubberized cloth for protection (Fig. 4). 


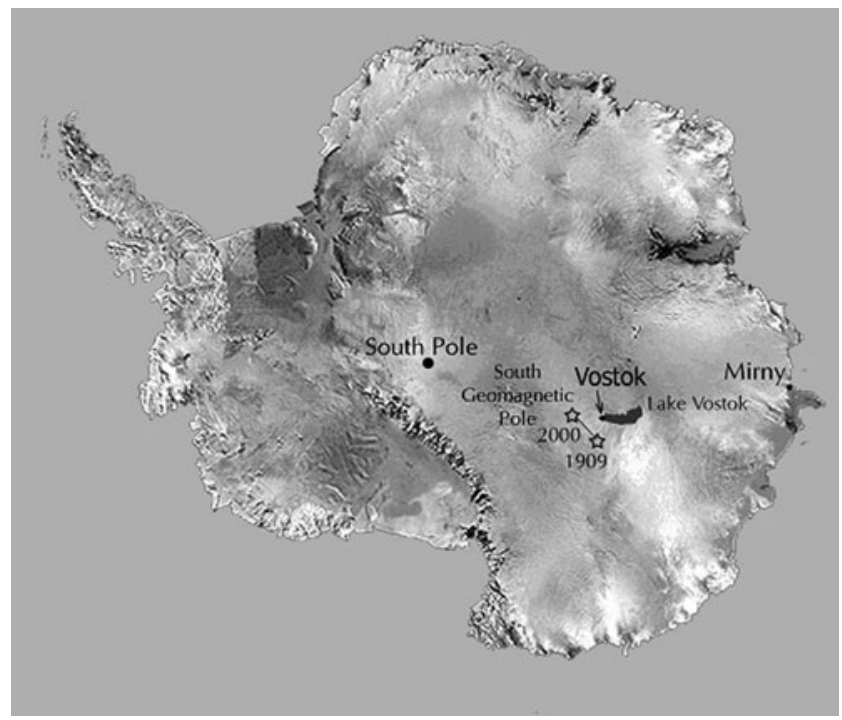

Fig. 1. Location of Vostok station, Vostok Subglacial Lake and South Geomagnetic Pole.

The first attempt at deep-hole drilling at Vostok began in April 1970 using the thermal drill, TELGA-14, previously tested at Mirny station. In this drill, meltwater was removed by a vacuum system and collected in a tank (Fig. 5a; Table 1). A dry hole, hole No. 1, reached 506.9 m by September 1970 (Table 2). In total, 293 drilling runs were completed (Barkov, 1970; Barkov and others, 1973; Kudryashov and others, 1973a, b).

The most serious difficulty encountered during drilling was contamination of the hole by impregnated graphite escaping from beneath the cable armor. The graphite settled to the bottom of the hole and impaired the heat transfer from the heating head to the ice, reducing the penetration rate by 20-30\%. A special, conically shaped, $3 \mathrm{~kW}$ heating head was used to melt a depression at the bottom of the hole into which the graphite settled. After the meltwater had frozen, the ice containing the contaminant was removed as part of a core. This procedure was repeated at depths of 276, 346, 419 and $498 \mathrm{~m}$. The contaminant also coated the walls of the water suction tubes and impaired the operation of the pump; both the suction tubes and pump had to be periodically cleaned. Drilling progressed slowly, without further serious complications except for two mishaps (Fisenko and others, 1974).

The first occurred at $15.7 \mathrm{~m}$ depth owing to a switch malfunction. A section of the drill broke off at the balance block and fell down the hole. It was retrieved using an adapter on the end of a column of rods, which was threaded into the broken section. The operation took about 6 hours.

At $497.4 \mathrm{~m}$ depth, a $20 \mathrm{~cm}$ steel rod was accidentally dropped to the bottom of the hole. A special heater assembly was used to melt a small central hole, which repositioned the rod from an inclined to a more vertical position. In this position, the rod would fit within the annular heating head of the TELGA drill. It was then recovered atop the next core. The operation took 14 days.

\section{6th SAE (1971)}

Drilling of hole No. 1 was continued. At the beginning of winter, due to carelessness, the TELGA-14 drill, unattached to a cable, was dropped to the bottom of the hole. It was

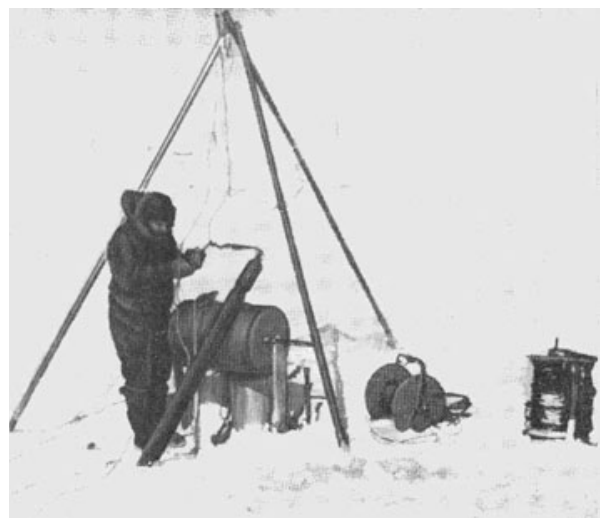

Fig. 2. First experience of thermal drilling at Vostok station during the 4th CAE (from Ignatov, 1962).

recovered using special grips (Fisenko and others, 1974). Later, at $560 \mathrm{~m}$ depth, as the drill was being hoisted, it became stuck near the bottom of the hole, probably because of the inadequate removal of meltwater. A whip-stock $4.5 \mathrm{~m}$ long was set at $505 \mathrm{~m}$ depth, and directional drilling began using a short thermal drill (total length $2 \mathrm{~m}$ ) with a conical drill head.

A new offset hole was started from $518 \mathrm{~m}$ depth (Fig. 6). To ensure free passage of the longer thermal drill, the deviated interval of the hole was enlarged, but unfortunately the old hole was reopened in the process. From that time on, the drill sometimes entered the new hole and sometimes the old one. At $534.4 \mathrm{~m}$ depth, drilling of the offset hole was stopped. The bottom part of the hole was filled with ice up to $471 \mathrm{~m}$ depth and a new directional drilling effort was started without using a whip-stock. The deviation was accomplished using a thermal drill with a special asymmetrical thermal head. By the end of winter, the depth of hole No. 1 reached $625.2 \mathrm{~m}$.

\section{7th SAE (1972)}

Drilling of hole No. 1 was continued using the modified thermal drill TELGA-14M. From $920 \mathrm{~m}$ depth, drilling was conducted using a spliced cable because the necessary length of cable was not available at the station. The lowering and hoisting was accompanied by repetitive jerking and sticking in the narrow parts of the hole (occurring 30 times

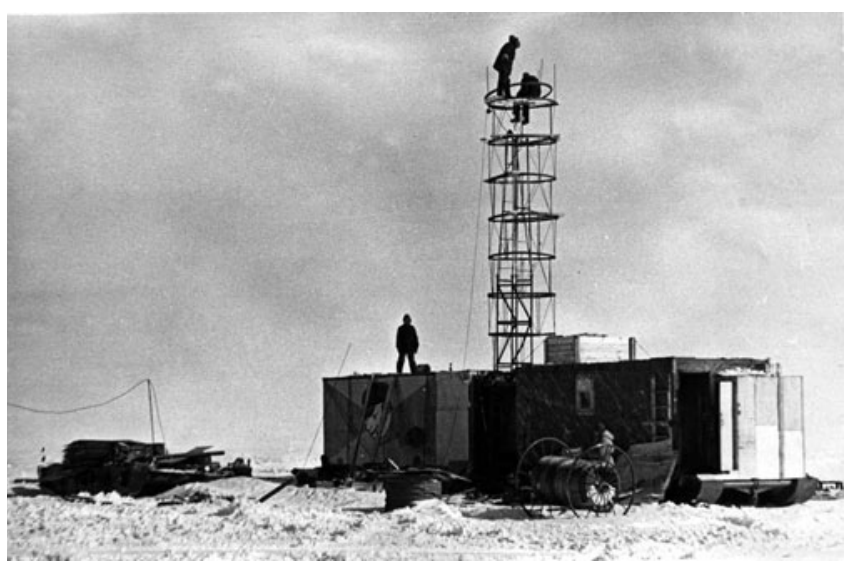

Fig. 3. The first drilling shelter at Vostok station under construction (summer season of 15th SAE, 1970). 


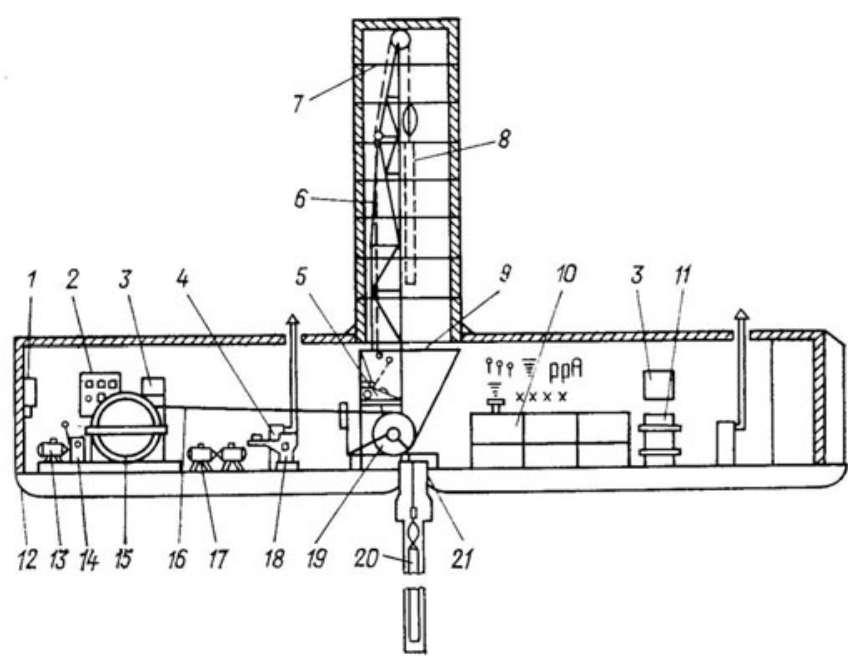

Fig. 4. Schematic diagram of the first drilling shelter at Vostok station: 1. electrical winch board; 2. control panel; 3. window aperture; 4. oil furnace; 5 . auxiliary hoist; 6. rig; 7. tower rings; 8. drill positioned over the hole; 9 . supporting framework; 10 . bench and instruments; 11 . fire prevention apparatus; 12 . steel sled; 13. hoist motor; 14. two-speed gear reducer; 15. main hoist; 16. cable; 17. generator-motor system; 18 . lathe; 19 . collapsible balance block; 20. drill in the hole; 21 . conductor.

during one run). Nevertheless, the hole reached $952.4 \mathrm{~m}$ in May 1972, making it the deepest dry hole in ice (Korotkevich and Kudryashov, 1976; Kudryashov, 1989). The final run occurred while the drill was being lowered to the bottom of the hole, when the winch-brake mechanism failed. The drill dropped to the bottom of the hole followed by the cable, which eventually became detached from the clamp holding it to the winch drum and fell into the hole. The drill and cable were eventually left in the hole.

A new offset hole was started. A cylindrical piece of ice was dropped from the surface into the hole, but unfortunately it got stuck at $30 \mathrm{~m}$ depth and efforts to dislodge it failed (Fisenko and others, 1974). From this depth, a new offset hole, hole No. 1-bis, was started and by the end of the year reached $774 \mathrm{~m}$ depth (Kudryashov and others, 1975, 1977).

\section{8th SAE (1973)}

The drilling in hole No. 1-bis was continued through the interval $774-780.2 \mathrm{~m}$, at which point the hole became inaccessible owing to an accident during hoisting. The
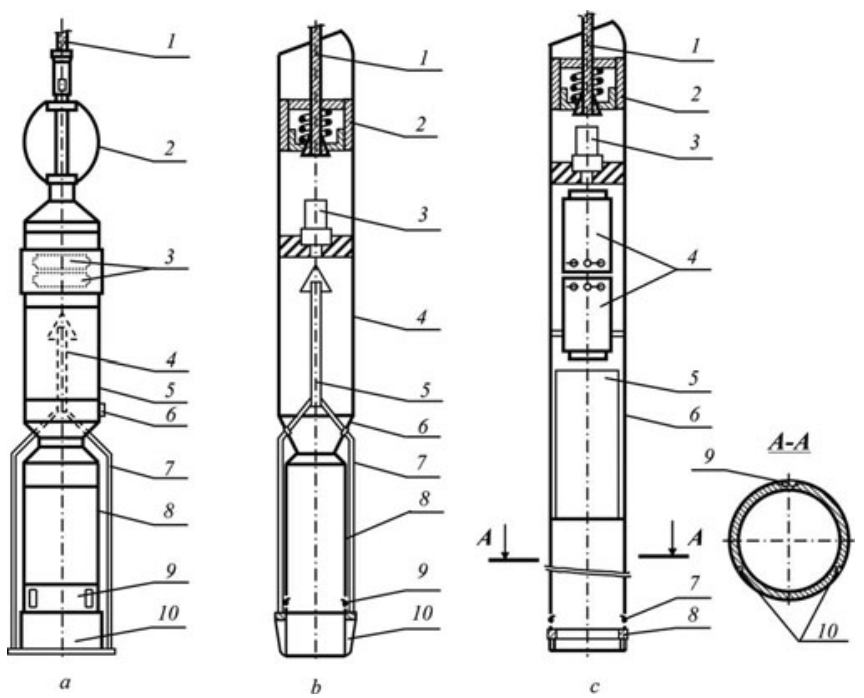

Fig. 5. Thermal drills designed in Leningrad Mining Institute: (a) Thermal drill TELGA-14M: 1. cable; 2. centering springs; 3. vacum pump; 4 . central water suction tube; 5 . water tank; 6 . valve; 7. water suction tubes; 8 . core barrel; 9 . core catcher; 10 . thermal head. (b) Thermal drill TBZS-152M: 1 . cable; 2. cable termination; 3. pump; 4. water tank; 5 . central water suction tube; 6 . connector; 7. water suction tubes; 8 . core barrel; 9 . core catcher; 10 . thermal head. (c) Thermal drill TBS-112VCh: 1. cable; 2 . cable termination; 3. pump; 4. electrical transformers; 5. removable water tank; 6. core barrel; 7. core catcher; 8 . thermal head; 9. electrical lines; 10. water suction tubes.

thermal head was stuck near the bottom and separated from the drill at $762 \mathrm{~m}$ depth. The drill itself then became stuck at $308 \mathrm{~m}$ depth (Vartykyan and others, 1977). The main reason for the accident was the inexperience of the new team, who did not recognize problems with the pumping of meltwater at the bottom of the hole. Ultimately, this led to the drill becoming stuck during hoisting (the drill profile 'swelled' because of refrozen water on its surface) during one of the first runs carried out by the new drilling team of the 18th SAE.

A new offset, hole No. 1-2bis, was started at 307 m depth in hole No.1-bis and reached $905 \mathrm{~m}$ depth (Kudryashov and others, 1977, 1991). Further drilling in this hole was stopped owing to the high risk of getting the drill stuck. Hole No. 1-2bis was available for several years for scientific observations of temperature, deviation from the vertical, and wall deformation (Dmitriev and others, 1978).

Table 1. Main characteristics of drills

\begin{tabular}{|c|c|c|c|c|c|c|}
\hline Type & $\begin{array}{l}\text { Max. depth drilled } \\
\text { m }\end{array}$ & $\begin{array}{c}\text { OD/ID of drill head } \\
\mathrm{mm}\end{array}$ & $\begin{array}{c}\text { Power of drill head } \\
\text { kW }\end{array}$ & $\begin{array}{l}\text { Length of core barrel } \\
\text { m }\end{array}$ & $\begin{array}{l}\text { Length of drill } \\
\qquad \mathrm{m}\end{array}$ & $\begin{array}{l}\text { Weight of drill } \\
\mathrm{kg}\end{array}$ \\
\hline TELGA-14M & 952 & $178 / 130$ & 3.5 & 2.5 & 8.0 & 200 \\
\hline TBZS-152M & 2502 & $152 / 114$ & 3.5 & 3.2 & 7.5 & 180 \\
\hline TBZS-132 & 2755 & $132 / 95$ & 3.0 & 3.0 & 7.2 & 120 \\
\hline TBS-112VCh & 2202 & $112 / 92$ & 4.5 & 2.0 & 9.0 & 180 \\
\hline TBPO-132 & - & $132 /-$ & 4.0 & - & 3.0 & 100 \\
\hline
\end{tabular}


Table 2. Deep drilling at Vostok station

\begin{tabular}{|c|c|c|c|c|c|c|}
\hline $\begin{array}{l}\text { Expedition No. } \\
\text { (year) }\end{array}$ & $\begin{array}{l}\text { Leader } \\
\text { of drilling team }\end{array}$ & $\begin{array}{l}\text { Hole } \\
\text { No. }\end{array}$ & $\begin{array}{l}\text { Drilling interval } \\
\qquad \mathrm{m}\end{array}$ & Type of drill & $\begin{array}{c}\text { Mean rate } \\
\text { of penetration } \\
\mathrm{m} \mathrm{h}^{-1}\end{array}$ & $\begin{array}{c}\text { Mean length } \\
\text { of run } \\
m\end{array}$ \\
\hline $\begin{array}{l}\text { Hole No. } 1 \\
15 \text { (1970) }\end{array}$ & N.I. Barkov & 1 & $0-506.9$ & TELGA-14 & 1.34 & 1.73 \\
\hline $16(1971)$ & N.I. Slyusarev & $\begin{array}{l}1 \\
1 \\
1\end{array}$ & $\begin{array}{r}506.9-560 \\
518-534.4 \\
471-625.2\end{array}$ & $\begin{array}{l}\text { TELGA-14 } \\
\text { TELGA-14 } \\
\text { TELGA-14 }\end{array}$ & $\begin{array}{l}1.3 \\
1.3 \\
1.3\end{array}$ & $\begin{array}{l}1.6 \\
1.6 \\
1.6\end{array}$ \\
\hline 17 (1972) & V.K. Chistyakov & $\begin{array}{l}1 \\
1 \text {-bis }\end{array}$ & $\begin{array}{c}625.2-952.4 \\
30-774\end{array}$ & $\begin{array}{l}\text { TELGA-14M } \\
\text { TELGA-14M }\end{array}$ & $\begin{array}{l}1.2 \\
1.2\end{array}$ & $\begin{array}{l}2.3 \\
2.3\end{array}$ \\
\hline $18(1973)$ & V.I. Kovalenko & $\begin{array}{l}1 \text {-bis } \\
1 \text {-2bis }\end{array}$ & $\begin{array}{l}774-780.2 \\
307-905\end{array}$ & $\begin{array}{l}\text { TELGA-14M } \\
\text { TELGA-14M }\end{array}$ & $\begin{array}{l}1.2 \\
1.2\end{array}$ & $\begin{array}{l}2.5 \\
2.5\end{array}$ \\
\hline $\begin{array}{l}\text { Hole No. } 2 \\
16 \text { (1971) }\end{array}$ & N.I. Slyusarev & 2 & $0-108$ & TELGA-14M & 1.3 & 1.6 \\
\hline 19 (1974) & B.S. Moiseev & 2 & $108-142$ & TBZS-152 & - & - \\
\hline 20 (1975) & R.N. Vostretsov & 2 & $142-450.4$ & TBZS-152 & 2.6 & 1.55 \\
\hline 21 (1976) & V.N. Bakhtyukov & 2-bis & 224-? & TBZS-152 & - & - \\
\hline $\begin{array}{l}\text { Hole No. 3G } \\
25 \text { (1980) }\end{array}$ & V.K. Chistyakov & $\begin{array}{l}3 G \\
3 G\end{array}$ & $\begin{array}{c}0-112 \\
112-1351\end{array}$ & $\begin{array}{l}\text { TELGA-14M } \\
\text { TBZS-152M }\end{array}$ & $\begin{array}{c}- \\
2.0\end{array}$ & $\begin{array}{r}- \\
2.0\end{array}$ \\
\hline $26(1981)$ & E.A. Zagrivny & $\begin{array}{l}3 \mathrm{G} \\
3 \mathrm{G} \\
3 \mathrm{G}-1\end{array}$ & $\begin{array}{l}1351-1500 \\
1500-1580 \\
1550-2004\end{array}$ & $\begin{array}{l}\text { TBZS-152M } \\
\text { TBS-112VCh } \\
\text { TBS-112VCh }\end{array}$ & $\begin{array}{l}2.0 \\
4.2 \\
4.2\end{array}$ & $\begin{array}{l}2.0 \\
1.65 \\
1.65\end{array}$ \\
\hline 27 (1982) & B.S. Moiseev & $3 \mathrm{G}-1$ & 2004-2083 & TBS-112VCh & 4.2 & 1.65 \\
\hline 29 (1984) & A.V. Krasilev & $3 G-2$ & 1968.5-2040 & TBS-112VCh & 3.9 & 1.45 \\
\hline 30 (1985) & A.A. Zemtsov & $3 G-2$ & 2040-2201.7 & TBS-112VCh & 3.7 & 1.55 \\
\hline $\begin{array}{l}\text { Hole No. 4G } \\
28 \text { (1983) }\end{array}$ & A.M. Shkurko & $\begin{array}{l}4 \mathrm{G} \\
4 \mathrm{G}\end{array}$ & $\begin{array}{r}0-120 \\
120-279\end{array}$ & $\begin{array}{l}\text { TELGA-14M } \\
\text { TBZS-152M }\end{array}$ & $\begin{array}{l}2.0 \\
1.9\end{array}$ & $\begin{array}{c}- \\
2.18\end{array}$ \\
\hline 29 (1984) & A.V. Krasilev & $4 \mathrm{G}$ & - & - & - & - \\
\hline $30(1985)$ & A.A. Zemtsov & $\begin{array}{l}4 \mathrm{G}-1 \\
4 \mathrm{G}-1\end{array}$ & $\begin{array}{l}120-167 \\
167-692\end{array}$ & $\begin{array}{l}\text { TELGA-14M } \\
\text { TBZS-152M }\end{array}$ & $\begin{array}{c}- \\
1.3\end{array}$ & $\begin{array}{r}- \\
1.8\end{array}$ \\
\hline 31 (1986) & V.P. Lobanov, B.S. Moiseev & $\begin{array}{l}4 \mathrm{G}-1 \\
4 \mathrm{G}-2 \\
4 \mathrm{G}-2\end{array}$ & $\begin{array}{l}692-752 \\
159-201 \\
201-779\end{array}$ & $\begin{array}{l}\text { TBZS-152M } \\
\text { TELGA-14M } \\
\text { TBZS-152M }\end{array}$ & $\begin{array}{c}1.3 \\
- \\
1.2\end{array}$ & $\begin{array}{c}2.3 \\
- \\
2.05\end{array}$ \\
\hline 32 (1987) & A.V. Krasilev & $4 \mathrm{G}-2$ & 779-1502 & TBZS-152M & 2.05 & 2.25 \\
\hline 33 (1988) & S.L. Mitin & $4 G-2$ & $1502-2383$ & TBZS-152M & 2.1 & 3.0 \\
\hline 34 (1989) & N.I. Vasiliev & $\begin{array}{l}4 \mathrm{G}-2 \\
4 \mathrm{G}-2\end{array}$ & $\begin{array}{r}2383-2428.5 \\
2428.5-2546.4\end{array}$ & $\begin{array}{l}\text { TBZS-152M } \\
\text { KEMS-112 }\end{array}$ & $\begin{array}{r}2.3 \\
12.5\end{array}$ & $\begin{array}{l}2.9 \\
2.5\end{array}$ \\
\hline $\begin{array}{l}\text { Hole No. 5G } \\
35 \text { (1990) }\end{array}$ & A.A. Zemtsov & $\begin{array}{l}5 G \\
5 G\end{array}$ & $\begin{array}{c}0-120 \\
120-1279.8\end{array}$ & $\begin{array}{l}\text { TELGA-14M } \\
\text { TBZS-152 }\end{array}$ & $\begin{array}{l}1.8 \\
2.1\end{array}$ & $\begin{array}{l}1.9 \\
2.9\end{array}$ \\
\hline $36(1991)$ & A.V. Krasilev & $5 \mathrm{G}$ & $1279.8-2502.7$ & TBZS-152 & 2.3 & 3.0 \\
\hline 37 (1992) & B.S. Moiseev & $\begin{array}{l}5 \mathrm{G}-1 \\
5 \mathrm{G}-1\end{array}$ & $\begin{array}{r}2232-2249.5 \\
2249.5-2270.7\end{array}$ & $\begin{array}{l}\text { TBZS-132 } \\
\text { TBZS-132 }\end{array}$ & $\begin{array}{l}2.0 \\
2.0\end{array}$ & $\begin{array}{l}1.0 \\
2.0\end{array}$ \\
\hline 38 (1993) & V.K. Chistyakov & $5 G-1$ & $2270.7-2755.3$ & TBZS-132 & 1.8 & 2.5 \\
\hline 40 (1995) & N.I. Vasiliev & $5 \mathrm{G}-1$ & 2755.3-3109 & KEMS-132 (KEMS-135) & 8.0 & 2.5 \\
\hline $41(1995 / 96)^{*}$ & N.I. Vasiliev & $5 G-1$ & $3109-3350$ & KEMS-132 (KEMS-135) & 8.0 & 2.2 \\
\hline $42(1997 / 98)^{*}$ & N.I. Vasiliev & $5 G-1$ & $3350-3523$ & KEMS-132 (KEMS-135) & 8.0 & 2.1 \\
\hline $43(1997 / 98)^{*}$ & N.I. Vasiliev & $5 \mathrm{G}-1$ & $3523-3623$ & KEMS-132 (KEMS-135) & 8.0 & 1.8 \\
\hline $51(2005-06)^{*}$ & N.I. Vasiliev & $5 \mathrm{G}-1$ & $3623-3650.2$ & KEMS-132 (KEMS-135) & 5.0 & 0.8 \\
\hline
\end{tabular}

${ }^{*}$ Drilling was conducted during the austral summer only. 


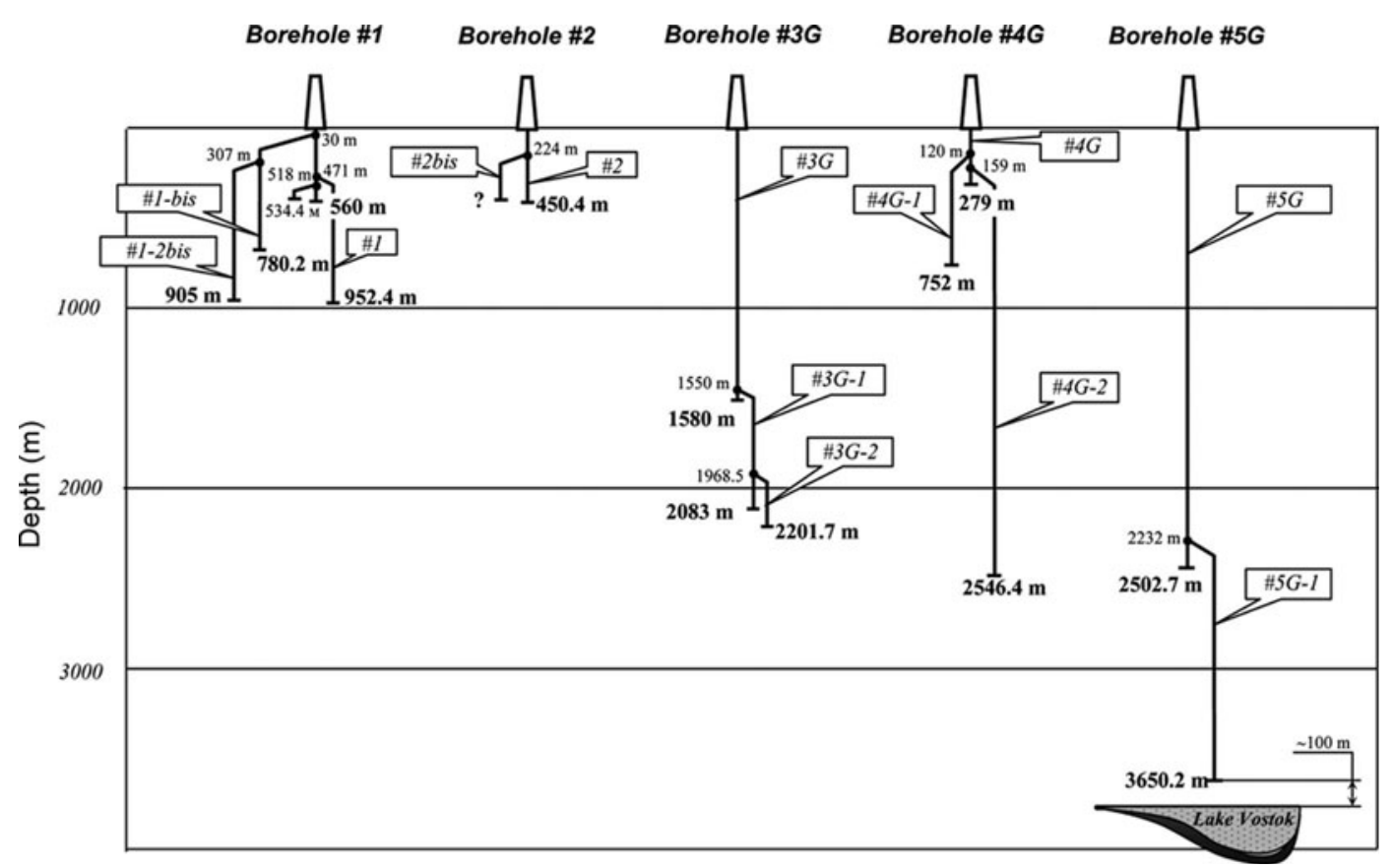

Fig. 6. Schematic of deep holes at Vostok station.

\section{DRILLING OPERATIONS IN HOLE NO. 2 (1971-76) AND EXPERIMENTAL HOLES (1977-79)}

\section{6th SAE (1971)}

During the summer season, the drilling shelter was reconstructed and extended to a length of nearly $30 \mathrm{~m}$ (Fig. 7). A special square tower $17.7 \mathrm{~m}$ high was built in the central part of the extended building. From this new set-up, an experimental hole, No. 2, was drilled to $108 \mathrm{~m}$ using a TELGA-14

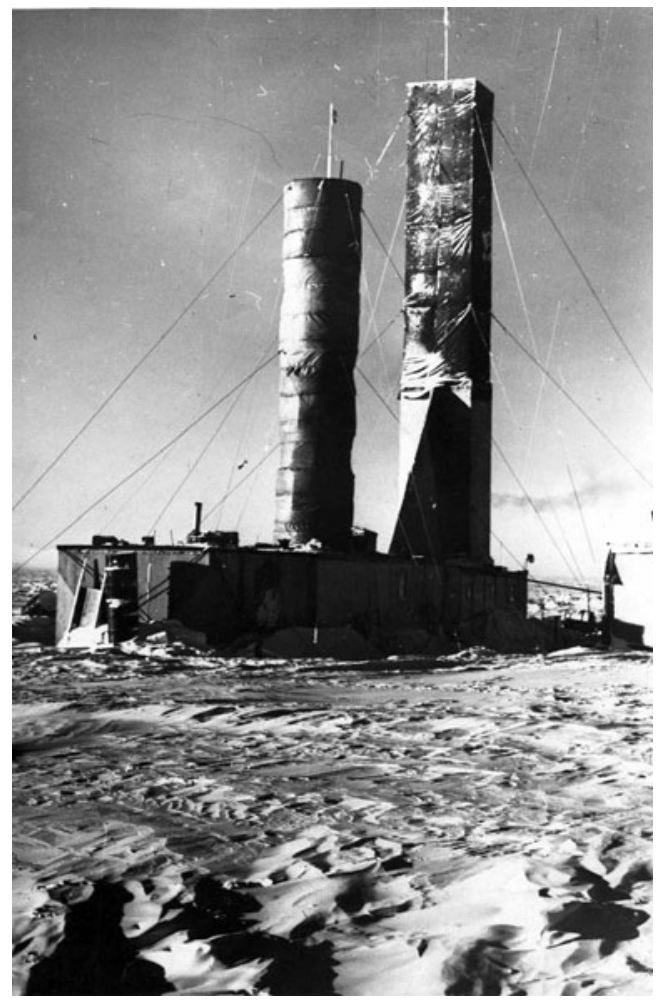

Fig. 7. Drill building at Vostok station (summer season of 16th SAE, 1971). thermal drill. The primary purpose was to drill a start-up hole for testing a new electromechanical drill, KEMS-152. The experiments were not carried out, because of imperfections in the new drill (Kudryashov and others, 1973b).

\section{9th SAE (1974)}

A casing was set in place in hole No. 2. It was made from steel tubing with an outer diameter (OD) of $168 \mathrm{~mm}$ and inner diameter (ID) of $154 \mathrm{~mm}$. The main problem was sealing the lower part of the casing to the ice. Water was poured into the hole from the surface. Hardly any of it reached the bottom, because most of it froze on the inner surface of the casing.

After the casing was cleaned, the hole was filled with a water-ethanol solution. The first attempts to drill in a deep fluid-filled hole using a TBZS-152 thermal drill (Fig. 5b; Table 1), with a water-ethanol solution as the fluid, encountered many problems. Owing to the dissolution of ice from the borehole walls, the water-ethanol solution decreased in concentration and formed an icy slush, which hindered drill penetration. In total, the depth interval 108$142 \mathrm{~m}$ was drilled with a mean ethanol consumption of $50 \mathrm{~L} \mathrm{~m}^{-1}$ (Kudryashov and others, 1983, 1991; Kudryashov and Yakovlev, 1991).

\section{0th SAE (1975)}

The drilling liquid in hole No. 2 was changed to a kerosenebased aircraft fuel, TS-1. During drilling, the liquid level was kept at 130-150 m depth. Drilling continued with the same TBZS-152 thermal drill down to $450.4 \mathrm{~m}$, where the drill became stuck, most likely because of problems in the water removal system (Zagrivny and others, 1981; Kudryashov and others, 1983). The cable was ruptured during the attempt to free the drill.

In the interval 142-450.4m, 199 drilling runs were completed. The power of the copper drill head was $6 \mathrm{~kW}$, and the power of the aluminum drill head was $5.3 \mathrm{~kW}$. The power of the heating elements in the water suction tubes 


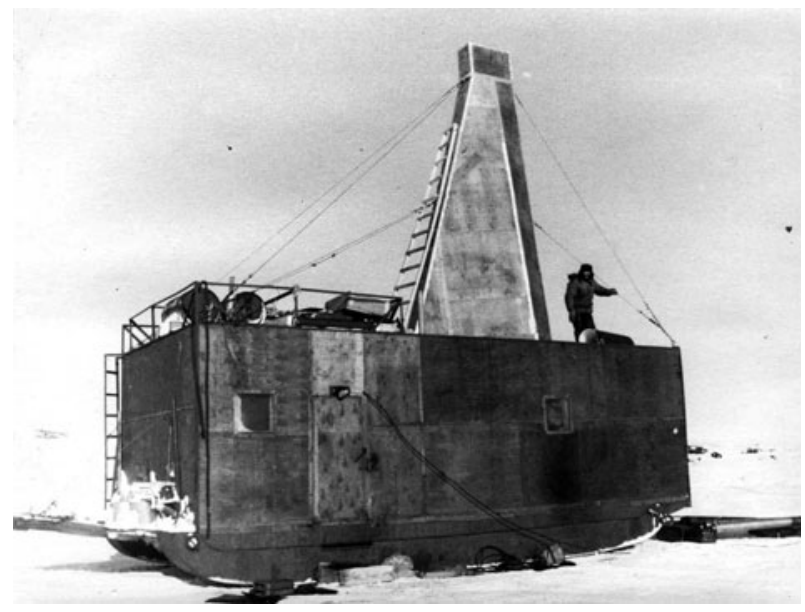

Fig. 8. The mobile drilling shelter PBU-2 towed to Vostok (summer season of 25th SAE, 1980).

was $120 \mathrm{Wm}^{-1}$; the power of the heating elements in the water tank was $1.5 \mathrm{~kW}$ per meter of water column (Zagrivny and others, 1980).

\section{1st SAE (1976)}

A new offset hole, No. 2-bis, was started at $224 \mathrm{~m}$ depth in the original hole No. 2 but the drill became stuck again. The final depth of hole No. 2-bis was not reported. According to our personal recollections, only a few runs in the new offset hole were made.

\section{2nd SAE (1977)}

Experiments with a TBZS-152 thermal drill were continued. Two unnumbered holes with depths of 171 and $300 \mathrm{~m}$ were drilled. Drilling was difficult, and a few serious accidents occurred. Drilling at Vostok was suspended in order to improve and test the technology of fluid-filled drilling. Such experimental drilling has been carried out on Vavilov glacier, Severnaya Zemlya archipelago, Russia, (Chistyakov and others, 1988) and, during the wintering of the 24th SAE at Gornaya base, at the $73 \mathrm{~km}$ mark of the Mirny-Vostok route (Kudryashov and others, 1991).

\section{DRILLING OPERATIONS IN HOLE NO. 3G (1980-86)}

\section{5th SAE (1980)}

The mobile drilling shelter, PBU-2, utilized for drilling at Gornaya base was towed to Vostok (Fig. 8) and used for drilling a new deep hole at Vostok station. The first $112 \mathrm{~m}$ of the new hole, No. 3G (G is the first letter of the Russian word glubokaya - 'deep'), was drilled as an uncased, dry hole using a TELGA-14M thermal drill. Below the firn-ice transition, the TBZS-152M thermal drill was used in a fluidfilled hole, the fluid consisting of aviation fuel TS-1 with densifier CFC11. The hole was extended to $1351 \mathrm{~m}$ by 17 December 1980 (Kudryashov and others, 1983, 1984a, b, 1991; Kudryashov, 1989; Kudryashov and Yakovlev, 1991).

\section{6th SAE (1981)}

The drilling of hole No. 3G was continued with a TBZS$152 \mathrm{M}$ drill over the interval 1415-1500 m. Beyond this

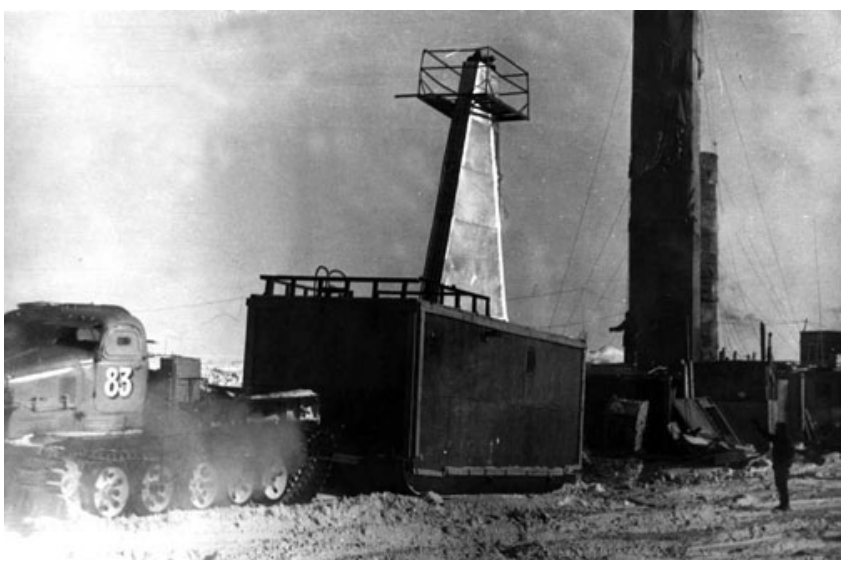

Fig. 9. The mobile drilling shelter PBU-3 installed above the mouth of hole No. 3G (summer season of 29th SAE, 1984).

depth, the TBS-112VCh thermal coring drill (Fig. 5c; Table 1) was used. This drill used a high-frequency power supply, which reduced the dimensions of the electric transformers positioned in the drill. At the surface, the power supply had a frequency of $2500 \mathrm{~Hz}$ and voltage of 800-1000 V. Passing through the cable, the electric voltage dropped to 700$900 \mathrm{~V}$. At the bottom, this primary voltage was reduced by electric transformers to the voltage of 20-25 V used in the drill. The water tank was not heated. The meltwater was collected in a tank and frozen inside. At the surface, the tank was removed and replaced with an empty tank. The core barrel was made from a thick-walled tube, with the water suction tubes and the electrical lines hidden within the wall.

The drilling rate was doubled to $3.5-4 \mathrm{~m} \mathrm{~h}^{-1}$ over the TBZS-152M with $5 \mathrm{~kW}$ of power. After reaching $1580 \mathrm{~m}$ depth, owing to problems with the meltwater removal system, the drill became stuck near the bottom of the hole. A new offset hole was started using another TBS-112VCh thermal drill with a length of $7.1 \mathrm{~m}$ at $1500 \mathrm{~m}$ depth, and in the interval 1550-1560 $\mathrm{m}$ a full-diameter core was recovered (Zagrivny and Moiseev, 1988). The new offset hole was designated hole No. 3G-1. A depth of $2004 \mathrm{~m}$ was reached by the end of the summer season (Kudryashov and others, 1984a, 1991; Zagrivny and others, 1985; Kudryashov and Yakovlev, 1991). Labeling of the ice core was kept as No. 3G down to $2083 \mathrm{~m}$, the end of hole No. 3G-1.

\section{7th SAE (1982)}

In early 1982, hole No. 3G-1 was advanced to $2083 \mathrm{~m}$ with a TBS-112VCh thermal drill (Zagrivny and others, 1985). A generator-room power-station fire on 12 April 1982 tragically took the life of the chief mechanic and curtailed further drilling (Kudryashov and others, 1991). On 26 December 1982, another fire destroyed the drilling shelter PBU-2 which housed the drilling complex for hole No. 3G, and drilling was suspended.

\section{9th SAE (1984)}

The mobile drilling complex PBU-3, which was transported from Mirny during the 28th SAE, was installed above the mouth of hole No. 3G (Fig. 9), replacing PBU-2 which had been destroyed by fire. The drilling operations in hole 


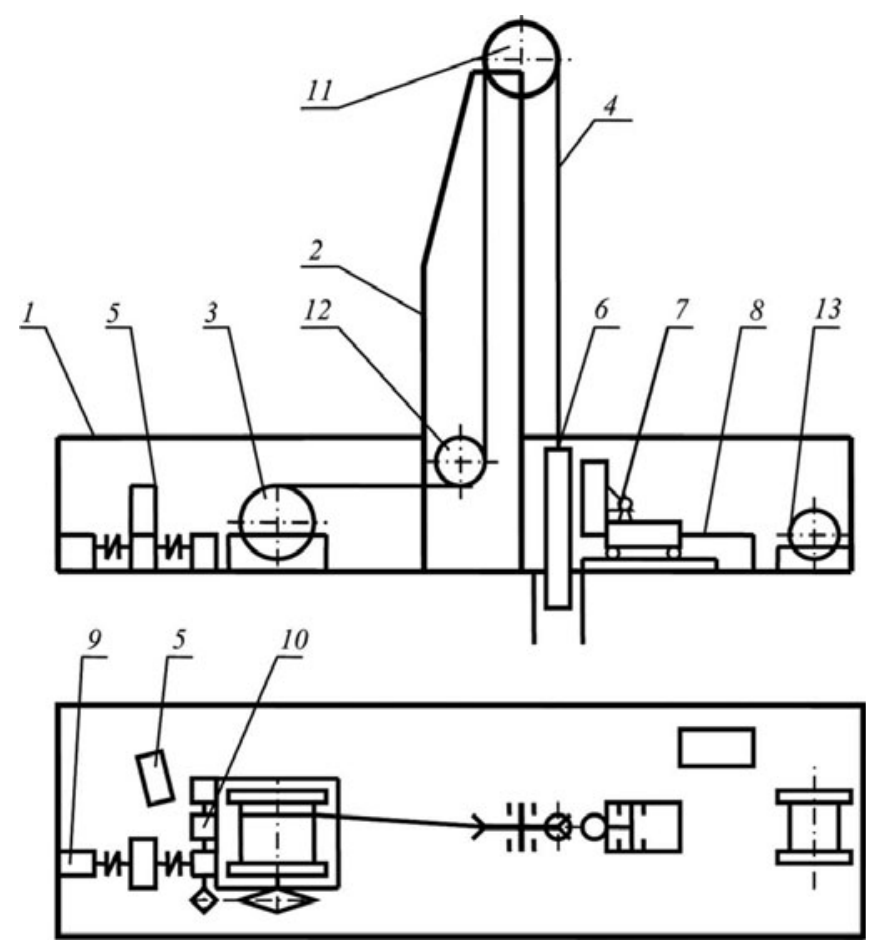

Fig. 10. Schematic diagram of the drilling building utilized for drilling of hole No. 4 and hole No. 5: 1. drilling shelter; 2. tower; 3. winch; 4. cable; 5 . control desk; 6 . drill; 7. drill-handling device; 8. d.c. generator; 9. electric motor; 10. worm reducer; 11 and 12. pulleys; 13. geophysical winch.

No. 3G-1 were resumed with a TBS-112VCh thermal drill, but the lower part of the hole had closed in during the long period of inactivity. During the enlarging or reaming process, a new offset hole was accidentally started at $1968.5 \mathrm{~m}$ depth. It was designated hole No. 3G-2 and was advanced to $2040 \mathrm{~m}$ (Kudryashov and others, 1991). Ice-core labeling was No. 3G-1 down to $2202 \mathrm{~m}$, the end of hole No. 3G-2.

\section{0th SAE (1985)}

Drilling in hole No. 3G-2 was resumed. A TBS-112VCh thermal drill reached $2201.7 \mathrm{~m}$ in August 1985 for a new ice-core drilling depth record (Kudryashov, 1989). The drilling was going on with continual enlarging of narrowing parts of the hole. Drill thermal heads were not properly adapted to the high hydrostatic pressure of drilling fluids, which led to premature burning of heating elements. In total, nearly 75 thermal drill heads were used in the last interval, 2040-2201.7 m.

\section{1st SAE (1986)}

The TBS-112VCh thermal drill was stuck in hole No. 3G-2 during enlarging operations in the interval 1935-1943 m (Kudryashov and others, 1991). Further activity in hole No. 3G-2 was stopped.

\section{DRILLING OPERATIONS IN HOLE NO. 4 (1982-89) 27th SAE (1982)}

The construction of a new stationary drilling complex was started for a new hole, No. 4G. It was built on two steel sleds with a $15 \mathrm{~m}$ mast, and $4000 \mathrm{~m}$ of a KG-95-180 type, sevenconductor armored cable (Kudryashov, 1989).

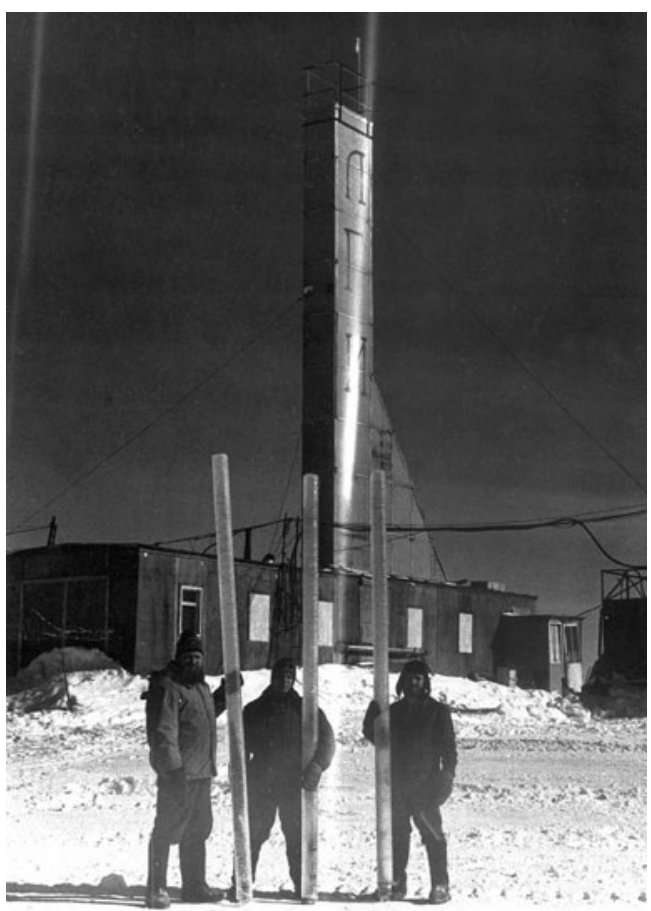

Fig. 11. Mean daily core production in SAE-32: three pieces of core, each with a length near $3 \mathrm{~m}$.

\section{8th SAE (1983)}

The construction of a new drilling complex was finished by 29 May 1983 (Fig. 10) and the new hole, No. 4G, was started on 3 July. Drilling in holes No. 3G and No. 4G overlapped by several years due to the efforts of two different shifts. The $178 \mathrm{~mm}$ diameter hole reached $120 \mathrm{~m}$ using a TELGA-14M thermal drill. After the hole was filled with liquid, a TBZS-152M thermal drill was used to advance it to $279 \mathrm{~m}$ by the end of the season, 12 February 1984 (Kudryashov and others, 1991).

\section{9th SAE (1984)}

Problems with the winch (the bolts of the winch drive-shaft coupling failed) used for hole No. 4G resulted in the loss of the TBZS-152M drill at the previous season's depth of $279 \mathrm{~m}$ (Kudryashov, 1989). Further drilling operations in hole No. 4G were curtailed.

\section{0th SAE (1985)}

The lost drill in hole No. 4G was bypassed with an offset hole No. 4G-1 started at $120 \mathrm{~m}$ by a TELGA-14M thermal drill; drilling continued to $167 \mathrm{~m}$ and then to $692 \mathrm{~m}$ depth with a TBZS-152M thermal drill (Kudryashov and others, 1991). Unfortunately, the initial hole was not packed with ice before deviation, which caused many problems thereafter.

\section{1st SAE (1986)}

Hole No. 4G-1 was advanced to $752 \mathrm{~m}$ with the TBZS-152M thermal drill. The old hole, No. 4G, was accidentally reopened because of the absence of ice plug at the place of deviation. This made it impossible to return to hole No. 4G-1, so a new offset hole, No. 4G-2, was started from hole No. 4G at $159 \mathrm{~m}$. A depth of $779 \mathrm{~m}$ was reached by 26 December 1986. Owing to inadequate centering of the drill, the inclination of hole No. 4G-2 reached $18^{\circ}$ in the 


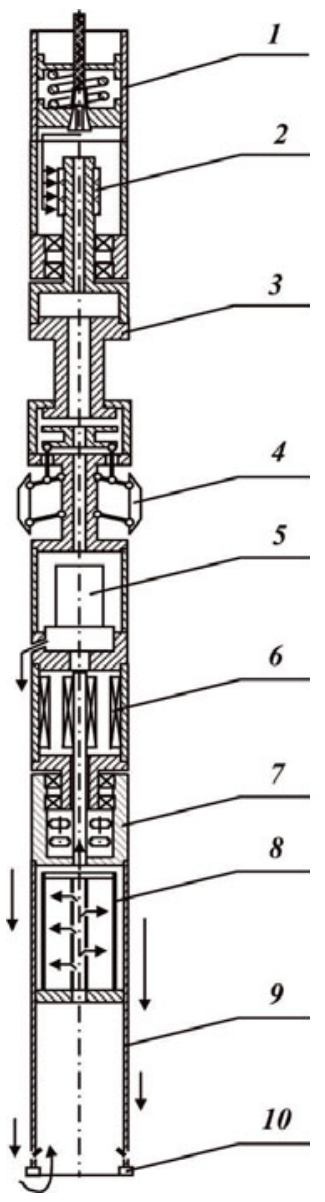

Fig. 12. KEMS-112 (KEMS-132) electromechanical drill: 1. cable termination; 2. electric chamber; 3 . hammer block; 4 . anti-torque system; 5. pump; 6 . electric drive motor; 7 . reducer; 8 . chip chamber including chip filter; 9. core barrel; 10. drill head.

depth interval 500-600 m (Kudryashov, 1989; Kudryashov and others, 1991).

\section{2nd SAE (1987)}

Drilling in hole No. 4G-2 continued with a TBZS-152M drill to $1502 \mathrm{~m}$ (Fig. 11). In order to reduce hole inclination, the interval 779-936 m was drilled with a shortened version of the TBZS-152M thermal drill (Kudryashov and others, 1991). The shortened version of the drill could penetrate with a smaller angle between axis of the drill and the vertical, allowing a reduction in the inclination.

\section{3rd SAE (1988)}

The continuation of drilling in hole No. 4G-2 with the TBZS$152 \mathrm{M}$ drill passed $2213 \mathrm{~m}$ by 1 November 1988, thereby exceeding the old record, and reached $2383 \mathrm{~m}$ by the end of the season. The hole inclination did not exceed $4^{\circ}$ (Kudryashov, 1989).

\section{4th SAE (1989)}

Deep drilling of hole No. 4G-2 using the TBZS-152M thermal drill was stopped at $2428.5 \mathrm{~m}$ in April 1989 owing to hole closure caused by a deficiency in fluid pressurization. Attempts to increase the density of the hole fluid with a high-density additive were not fully successful.

In June 1989, drilling resumed with an electromechanical drill referred to as KEMS-112 or KEMS-132 (KEMS-135)

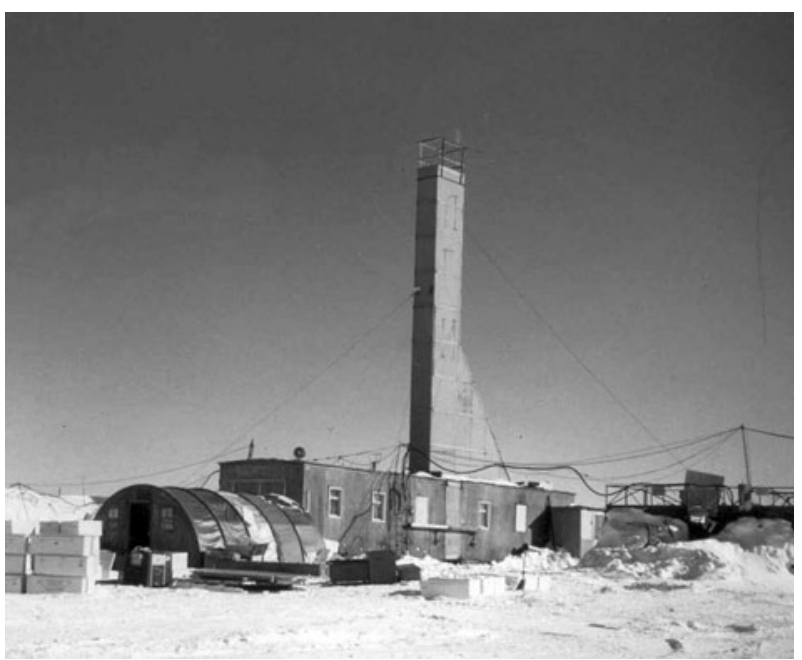

Fig. 13. Drill building at Vostok station (summer season of 35th SAE, 1990).

depending on ODs of the core barrel and the drill-head cutters (Fig. 12; Table 1). The upper part of the drill (motorgear section, pump, cable termination, etc.), except the skates of the anti-torque sections, is the same in all versions of the drill. The lower part of the drill (core barrel and chip chamber) of the KEMS-112 type is assembled from steel tubes with OD/ID of $108 / 99 \mathrm{~mm}$, and the KEMS-132 (KEMS135) from tubes with OD/ID of $127 / 117 \mathrm{~mm}$. The drive motor for either design was three-phase, $220 \mathrm{~V}$, with a capacity of $2.2 \mathrm{~kW}$. A two-stage gear reducer lowered the speed from $2800 \mathrm{rpm}$ to $230 \mathrm{rpm}$. Testing had been conducted in the Arctic prior to the drilling at Vostok.

In the first 20 runs, the length per run was $<0.1 \mathrm{~m}$. The drill was stuck at 2431.7 and $2437.5 \mathrm{~m}$, but freed in 5 days and 2 hours, respectively. After every $10-15 \mathrm{~m}$, the hole was enlarged with a $135 \mathrm{~mm}$ cutting head. At $2546.4 \mathrm{~m}$ depth, drilling was interrupted for 16 days and a new $4000 \mathrm{~m}$ long cable was installed. The drill became stuck on the first run, $1 \mathrm{~m}$ above the bottom. The operation was left for a year with tension on the cable (Vasil'yev and others, 1993; Kudryashov and others, 1994).

\section{5th SAE (1990)}

The drilling complex was moved. A small shelter with pulling equipment was built above the mouth of hole No. 4G. The drill was still stuck in the hole. During a recovery attempt, the cable failed near the surface in November 1990 (Kudryashov and others, 1994).

\section{DRILLING OPERATIONS IN HOLE NO. 5G (1990-2006)}

\section{5th SAE (1990)}

In January 1990 the drilling complex was moved $25 \mathrm{~m}$ to the west (Fig. 13 shows the drilling shelter as it appeared during SAE-35). A new hole, No. 5G, was started on 20 February 1990, using a TELGA-14M thermal drill to $120 \mathrm{~m}$ depth in 62 runs (Fig. 14). Beyond this depth, another thermal drill for fluid-filled holes, TBZS-152M, was used. A depth of $1279.8 \mathrm{~m}$ was achieved in 398 runs with the TBZS-152M drill by the end of the season, 29 January 1991 (Tchistiakov and others, 1994; Kudryashov and others, 1998a, b, 2002). 


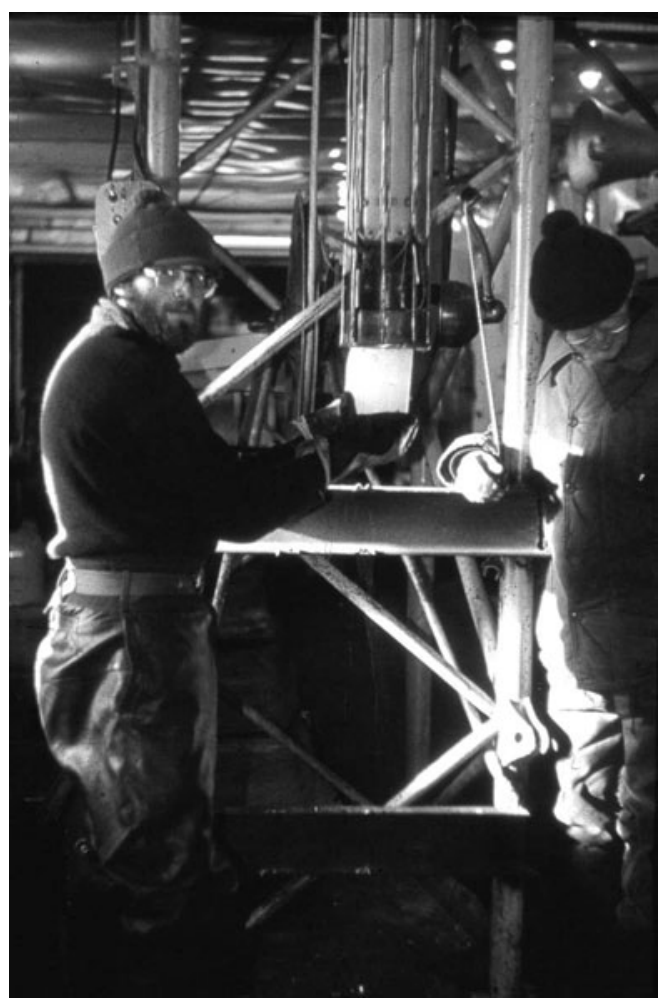

Fig. 14. One of the first cores recovered by TELGA-14M thermal drill in hole No. 5G.

\section{6th SAE (1991)}

Drilling in hole No. 5G reached $2502.7 \mathrm{~m}$ in December 1991, with the TBZS-152M thermal drill completing 408 runs. The round-trip time to the bottom of the hole and back increased to 2.6 and 1.8 hours respectively, at $2500 \mathrm{~m}$ depth. The inclination varied between $0.2^{\circ}$ and $0.6^{\circ}$ down to $2000 \mathrm{~m}$, then increased gradually from $0.4^{\circ}$ to $1.8^{\circ}$ at $2250 \mathrm{~m}$. At the end of December, the drill became stuck at $2259 \mathrm{~m}$ during a trip up-hole. The problem was caused by hole closure from insufficient fluid pressurization. All attempts at recovery failed and the cable was pulled out of the top of the drill (Tchistiakov and others, 1994; Dmitriev and others, 1995; Kudryashov and others, 1998a, b, 2002).

\section{7th RAE (1992)}

Densifier HCFC 141b was added to hole No. 5G, increasing the fluid density to $900 \mathrm{~kg} \mathrm{~m}^{-3}$. About $35 \mathrm{~m}$ of artificial core was dropped on top of the stuck drill, creating a new hole bottom at $2232 \mathrm{~m}$. A shortened version of the TBZS-132 thermal drill, $6 \mathrm{~m}$ long, was used to drill a new offset hole, No. 5G-1. From $2249.5 \mathrm{~m}$ depth, drilling was continued with a TBZS-132 drill with a normal length of $8 \mathrm{~m}$, to $2270.7 \mathrm{~m}$ depth by the end of the winter and to $2341.8 \mathrm{~m}$ by the end of the summer season. The main differences between the TBZS-132 and TBZS-152 thermal drills were the OD and ID of the drill head and the tubing used for the core barrel and water tank (Kudryashov and others, 1998a, b).

\section{8th RAE (1993)}

From August 1993, following the collapse of the USSR, ice coring and core research at Vostok station was conducted by a joint Russian-French-US project. The Russians maintained the station and conducted the drilling operations, the French

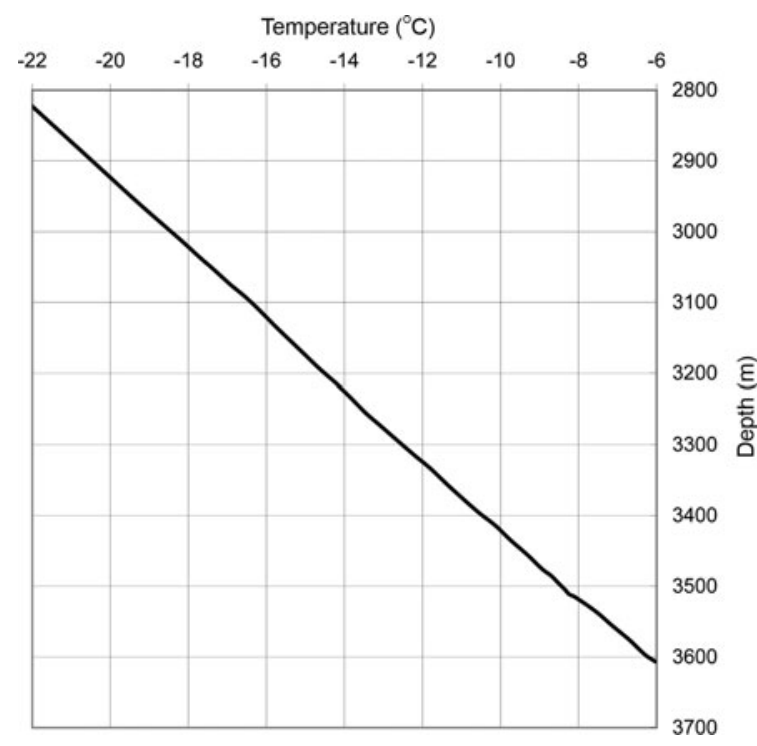

Fig. 15. Temperature profile in the lower part of hole No. 5G.

provided technical equipment and the Americans provided logistical support. Since that time, the core has been divided between the three partners to the agreement.

Hole No. 5G-1 reached $2755.3 \mathrm{~m}$ depth with the TBZS132 drill. The depth was a new record for thermal drilling in ice. From 18 September 1993, drilling ceased because the supply of drilling fluid was exhausted (Kudryashov and others, 1998a, b, 2000, 2002).

\section{9th RAE (summer season 1993/94)}

During the summer season, the upper part of hole No. 5G-1 was enlarged from 180 to $220 \mathrm{~mm}$ using an electromechanical reaming technique. The hole was cased with fiberglass tubing and, using a thermal shoe at the bottom of the casing, it was sealed at $120 \mathrm{~m}$ depth so that hole fluid could be retained throughout the permeable zone. The OD/ID of the casing tubes was $179 / 165 \mathrm{~mm}$. The OD of the connecting couplings of the $6 \mathrm{~m}$ long sections was $215 \mathrm{~mm}$. It was discovered, however, that fluid could only be maintained to a maximum height of $66 \mathrm{~m}$ below the surface, owing to a leak at an uncertain location (Kudryashov and others, 2000, 2002). On 10 February 1994, Vostok station was temporarily closed for the winter for logistical and economic reasons.

\section{0th RAE (1995)}

On 22 November 1994, the traverse from Mirny reached Vostok, and on 27 November the station was fully reopened. Drilling operations in hole No. 5G-1 were resumed. First, to compensate for the ice overburden pressure, the density of the drilling fluid in the hole was increased. Then the hole was enlarged between 2200 and $2755 \mathrm{~m}$ from 134 to $139 \mathrm{~mm}$ in diameter with an electromechanical reamer to facilitate lowering and raising the drill. Drilling began with the KEMS-132 electromechanical drill in February 1995 and reached 3109 m depth in September 1995, when the drilling was stopped because all of the densifier supply had been consumed. An average drilling run of $2.8 \mathrm{~m}$ was achieved, but beyond $2930 \mathrm{~m}$ the length of the drilling runs decreased dramatically because of sticking and jamming of the drill (Kudryashov and others, 1998a, b, 2000, 2002). The temperature in the hole at $2930 \mathrm{~m}$ depth was near $-20^{\circ} \mathrm{C}$ 


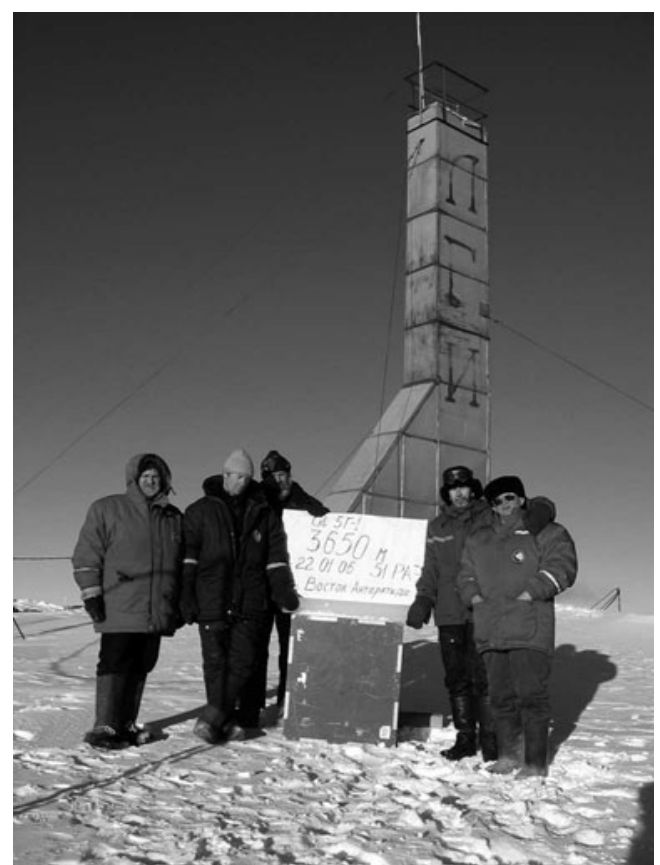

Fig. 16. Drilling team of the 2005/06 summer season with record core from $3650 \mathrm{~m}$ depth. From left to right: A. Krasilev, A. Ekaikin, V. Zubkov, A. Dmitriev and N. Vasiliev.

(Fig. 15), too cold to consider 'warm ice' as the main reason for complications. Partially our problems can be explained by changing ice properties, in particular changing ice crystal size (see below).

\section{1st RAE (summer season 1995/96)}

A supply of the densifier HCFC 141b was delivered to the station by C-130 aircraft from the US McMurdo Station, and a large amount of densifier was added to hole No. 5G-1 to raise the fluid density. Drilling was continued, and reached $3350 \mathrm{~m}$ by January 1996 using the KEMS-132 drill with a cutter diameter of $135 \mathrm{~mm}$. The hole was enlarged to $137 \mathrm{~mm}$ every $25-30 \mathrm{~m}$. Increasing difficulties with chip collection in the warmer ice after $3000 \mathrm{~m}$ resulted in shorter cores and the eventual stoppage of drilling (Kudryashov and others, 1998a, b, 2000, 2002). A traverse consisting of 16 vehicles started from Mirny to Vostok on 12 November 1995, but mechanical problems with the vehicles forced a decision to cancel the traverse at the $645 \mathrm{~km}$ mark. For the first time in Soviet and Russian Antarctic expeditions, a traverse failed to reach Vostok station. On 24 January 1996 all the people were evacuated by C-130 aircraft and Vostok station was closed down again. Future drilling operations were to be reduced to short Antarctic summer seasons.

\section{2nd RAE (summer season 1996/97)}

Vostok station was reopened and the drilling of hole No. 5G-1 was resumed with the KEMS-132 electromechanical drill. The drill head was equipped with special shoes to limit the pitch of the cutters, which allowed drilling operations to resume. However, at the end of this season the decrease in the length of the drilling runs (up to a complete stoppage of coring) reoccurred. It is worth noting that in the two latter cases the stoppage was not associated with jamming of the drill head. Drilling efficiency was reduced dramatically, and sticking of the drill head due to the presence of

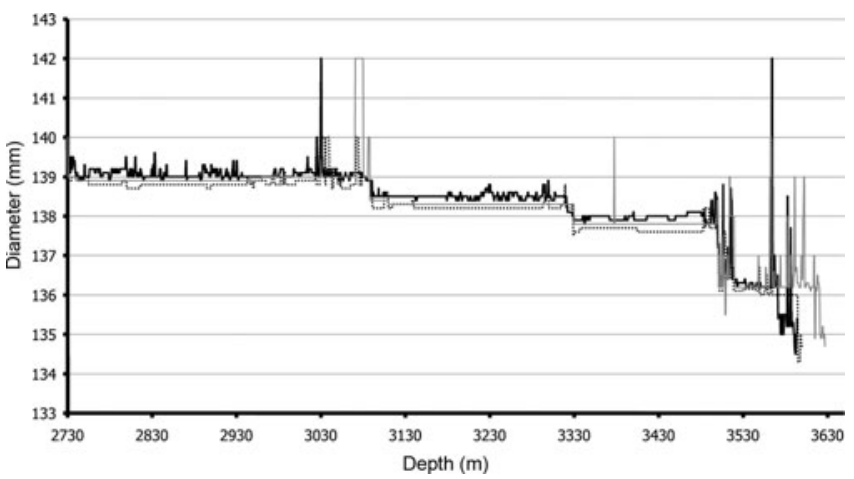

Fig. 17. Diameter of hole No. 5G-1 versus depth at different times: 25 January 1998 (thick solid line); 29 December 1999 (dotted line); and 23 January 2006 (thin solid line).

ice chips at the hole bottom was occurring immediately after the beginning of a drilling run. Nevertheless, hole No. 5G-1 reached $3523 \mathrm{~m}$ by the end of the season at the end of January 1997 (Kudryashov and others, 2002).

\section{3rd RAE (summer season 1997/98)}

Despite the improvements that have been brought into the design of some units of the drill, at the beginning of the 43rd RAE season the drilling was unstable again. Only after certain changes in the geometry of the cutter, aimed at decreasing sticking of the ice chips to the drill head, could the drilling be continued. To prevent icing on drill-head cutters, the clearance angle was increased to $15^{\circ}$; in addition, the cutters and the body of the drill head were covered with a thin Teflon layer. These measures significantly increased the efficiency of ice destruction and chip removal from the hole bottom. As a result, ice coring during the 43rd RAE season was performed in the routine mode of operations. Drilling was stopped at $3623 \mathrm{~m}$ in January 1998, about $130 \mathrm{~m}$ above Vostok Subglacial Lake (Kudryashov and others, 2002).

During this drilling season, at $3538 \mathrm{~m}$ depth the drill passed from meteoric ice into accretion ice which formed by freezing of the subglacial lake. There was no visible change in drilling mode except the appearance of oversize ice pieces at the bottom of the hole (see next subsection).

Between 1998 and 2005, borehole geophysical measurements were performed.

\section{1st RAE (summer season 2005/06)}

After 8 years, hole No. 5G-1 was reopened for drilling. At the beginning of the summer season, the drilling equipment and the hole itself were carefully inspected. On 31 December 2005, the first productive run was made by the electromechanical drill KEMS-135, and $0.5 \mathrm{~m}$ of new core was recovered. The new geometry of cutters for drilling of 'warm ice' was tested: the bottom-side form of the cutters had a dihedral shape, which allowed the clearance angle to be increased up to $30^{\circ}$. This gave stabilization to the drilling process. As a result, hole No. 5G-1 was deepened to $3650.2 \mathrm{~m}$, with an average core length of $0.7-0.8 \mathrm{~m}$ per run (Fig. 16). On 25 January 2006, the seasonal operations at Vostok ceased.

The hole diameter was measured by a special borehole logger of lever type with a precision of $0.2 \mathrm{~mm}$. The diameter change over time was insignificant and lay in the range of measurement accuracy (Fig. 17). The drilling-fluid 


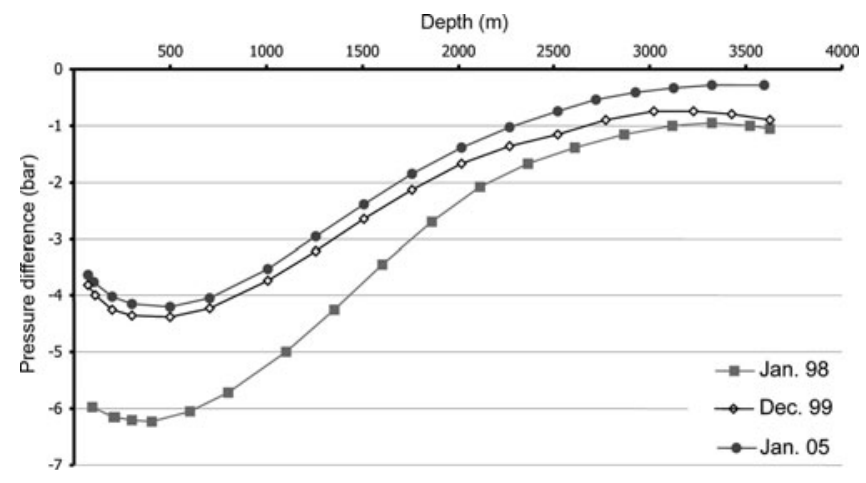

Fig. 18. Pressure difference on the walls of hole No. 5G-1.

pressure in the hole was measured, and the pressure difference on the hole walls was estimated (Fig. 18). The pressure difference at depths close to the hole bottom is near zero, which indicates satisfactory compensation of the ice overburden pressure. The liquid level is at $95 \mathrm{~m}$ depth; the average fluid density is $928 \mathrm{~kg} \mathrm{~m}^{-3}$.

\section{Drilling performance in 'warm ice'}

Electromechanical drilling of 'warm ice' is characterized by sudden losses of drilling progress, which are caused by the rapid gluing together of ice cuttings forming ice spots and rings on the surface of the drill equipment (especially near the drill head). This blocks the fluid circulation, and the normal drilling process is stopped. If the drilling is continued, there is a high risk of getting the drill stuck. This effect was noticed in all recent drilling projects in Greenland (NorthGRIP) and Antarctica (Dome C, Dronning Maud Land and Dome F).

The first problems that could be connected with the peculiar properties of 'warm ice' appeared in hole No. 5G-1 at depths near $3000 \mathrm{~m}$. The instability of drilling progressively increased with depth. In particular, unexpected jamming of the drilling head often occurred even at low drilling pressures, that is, at penetration speeds of about $1 \mathrm{~m} \mathrm{~h}^{-1}$ or less. This was accompanied by significantly shorter drilling runs. At depths below $3480 \mathrm{~m}$, the efficiency of drilling was reduced dramatically, and sticking of the drill head due to the presence of ice chips at the bottom of the hole occurred immediately after beginning a drilling run.

We explain our problems in terms of the changing ice properties, in particular by changes of ice crystal size and ice surface structure. In Figure 19, two plots - run length and

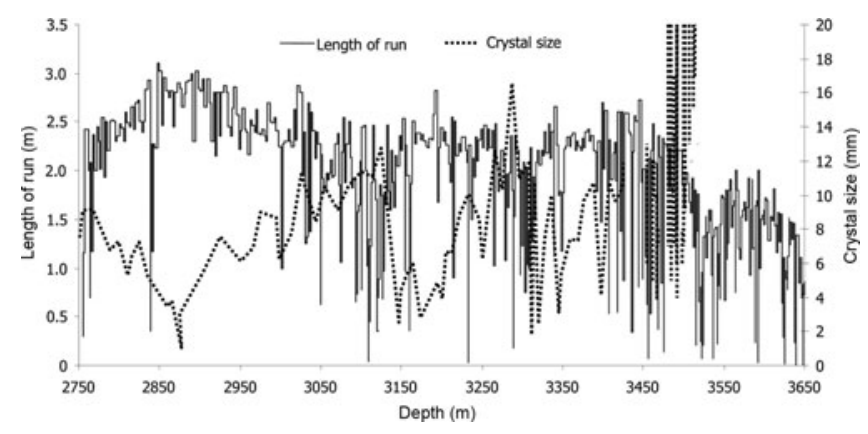

Fig. 19. Length of run and ice crystal size versus depth in hole No. $5 \mathrm{G}-1$.

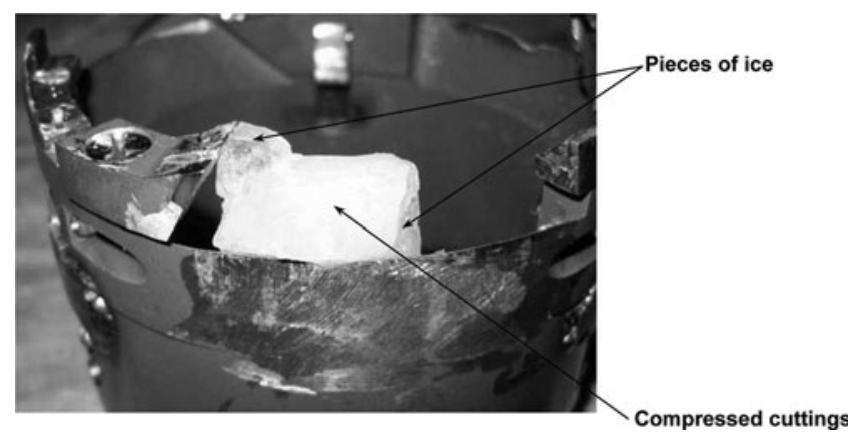

Fig. 20. Ice pieces and compressed cuttings between drill-head cutters.

crystal size vs depth - are combined (data on ice crystal size are from Lipenkov and Barkov (1998) and Lipenkov and others (2000)). The correspondence between these plots is clearly visible: increasing ice crystal size leads to decreasing run length. Certain improvements were brought into the design of the drill head and chips chamber that allowed the drilling operations to proceed, but the tendency toward decreasing run length continued.

The ice cuttings of fine-grained ice with crystal sizes less than $5 \mathrm{~mm}$ consist of chips with dimensions of $1-2 \mathrm{~mm}$ and more. The cutting process of the coarse-grained ice is different: the dimensions of the ice cuttings are much less, not exceeding $0.5 \mathrm{~mm}$. At the same time, many very small chips like ice fines were formed. The fine chips easily plugged the filter in the chips chamber, sharply increasing the hydraulic resistance in the drill circulation system and decreasing the fluid flow rate. The drop in the flow rate caused ice plugs to form in the most critical places of the drill, i.e. near the cutters and the drill head.

This situation is exacerbated by water appearance on the ice surface. According to the theory of Fletcher (1970), on the surface of ice with a temperature of $-6^{\circ} \mathrm{C}$ the quasiwatery layer with a thickness of near $10 \AA\left(10^{-9} \mathrm{~m}\right)$ appears instantaneously, and at temperatures near $0^{\circ} \mathrm{C}$ the thickness of the layer increases to several hundred ångstroms. Fletcher's conclusions were made for ice under atmospheric pressure. Taking into account the depression of the ice melting point under pressure, we can estimate the change in adhesion properties of the ice starting from depths near $3000 \mathrm{~m}$.

Another problem with coarse-grained-ice drilling was the formation of oversize pieces of ice that were split off the core while the core was broken from the bottom by core catchers. Higher in the hole, such ice pieces were finegrained and easily broken by drill-head cutters. Breaking the coarse-grained ice pieces required a considerably higher force impact. Ice pieces with dimensions larger than clear openings cannot be destroyed by the cutters, and so initiate ice-plug formation in the space between two cutters (Fig. 20). Even though the two other openings of the drill head were still unblocked, eventually the penetration stopped (our experience showed that it was possible to drill no more than $50-100 \mathrm{~mm}$ having such an ice plug in the opening between cutters).

We can imagine the following interaction modes between cutters and oversize pieces of ice. If the oversize ice pieces enter the opening of the drill head, it is impossible to penetrate at all, even at a cutter load equal to the drill weight 


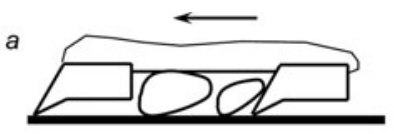

b

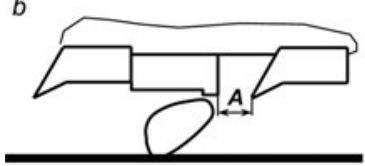

d

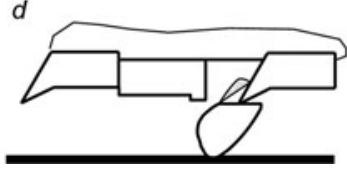

$c$
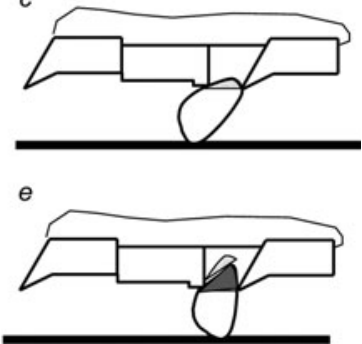

Fig. 21. Scheme of interaction between cutters and oversize pieces of ice.

(Fig. 21a). To avoid such a mode it is necessary to limit the space between cutters with the help of a fixed stop installed between cutters. The size $A$ (Fig. 21b) should be less than the clearance between the core and the inner surface of the core barrel. In this case, the destruction of oversize pieces of ice should proceed as shown in Figure 21b-e. The oversize pieces of ice cannot enter the opening of the drill head and so begin to be cut by the cutters. The ice cuttings produced look like thin plates with a width equal to cutter width and a thickness of a few millimeters. During experimental drilling with a modified drill head, we have repeatedly found such ice plates in the chips chamber.

The width of these plates is not small enough for them to pass through the clearances of the drill circulation system. To decrease the width of such ice plates, special grooves were made in the bottom side of the cutters, dividing the edge of the cutters into two working areas (Fig. 22).

\section{PLANNING PENETRATION AND SAMPLING OF VOSTOK SUBGLACIAL LAKE}

Since 1998, a technique for the continued penetration of hole No. 5G-1 to Vostok Subglacial Lake has been studied (Verkulich and others, 2002). We propose to access the lake and sample the water in three stages, as follows (Fig. 23).

The first stage includes an additional deepening of hole No. 5G-1 to a depth near $3720 \mathrm{~m}$, leaving about a $30 \mathrm{~m}$ thick ice layer to prevent contamination of the lake by the drilling fluid. This can be accomplished with electromechanical drill KEMS-135, which has been successfully employed here. Then a new, ecologically friendly liquid (silicone oil) is delivered to the hole bottom by a special tanker. It is anticipated that this hydrophobic liquid, being heavier than the drilling fluid and lighter than water, will

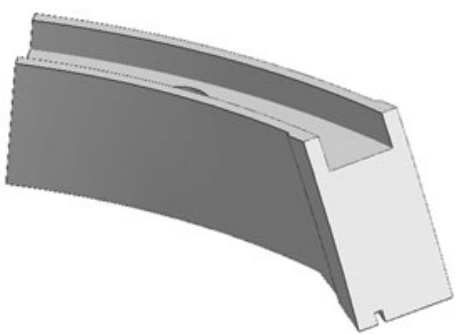

Fig. 22. Modified cutter.

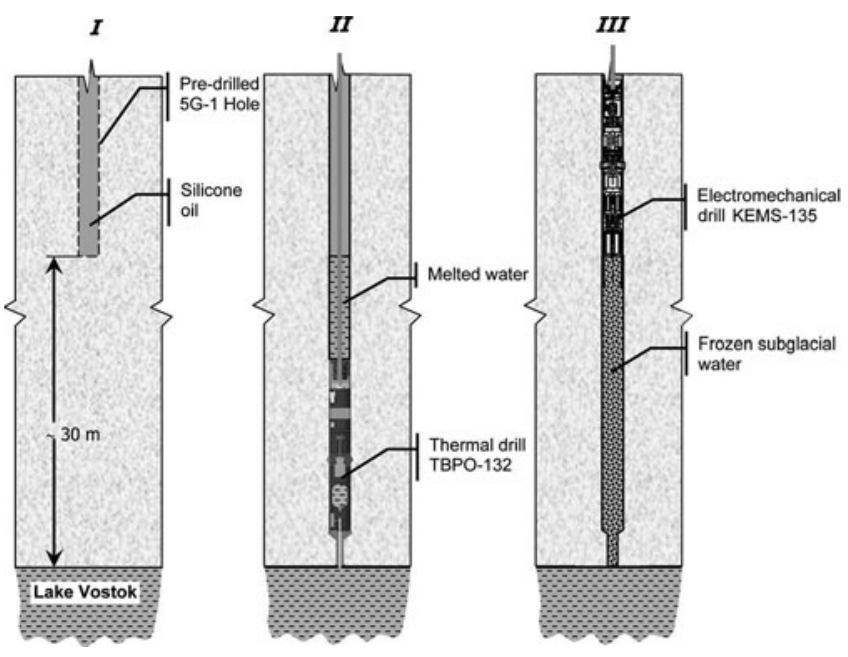

Fig. 23. Scheme of penetration and sampling of Vostok Subglacial Lake.

create a $100 \mathrm{~m}$ thick 'buffer layer' in the bottom part of the hole. The hydrostatic pressure at the bottom of hole No. 5G-1 should be slightly lower than the overburden ice pressure.

The second stage is drilling up to the ice-water interface. This will be carried out by thermal drill TBPO-132 in one operation. Two versions of thermal drill TBPO-132 (without container for subglacial water and with it) are shown schematically in Figure 24. At the instant the tip of the

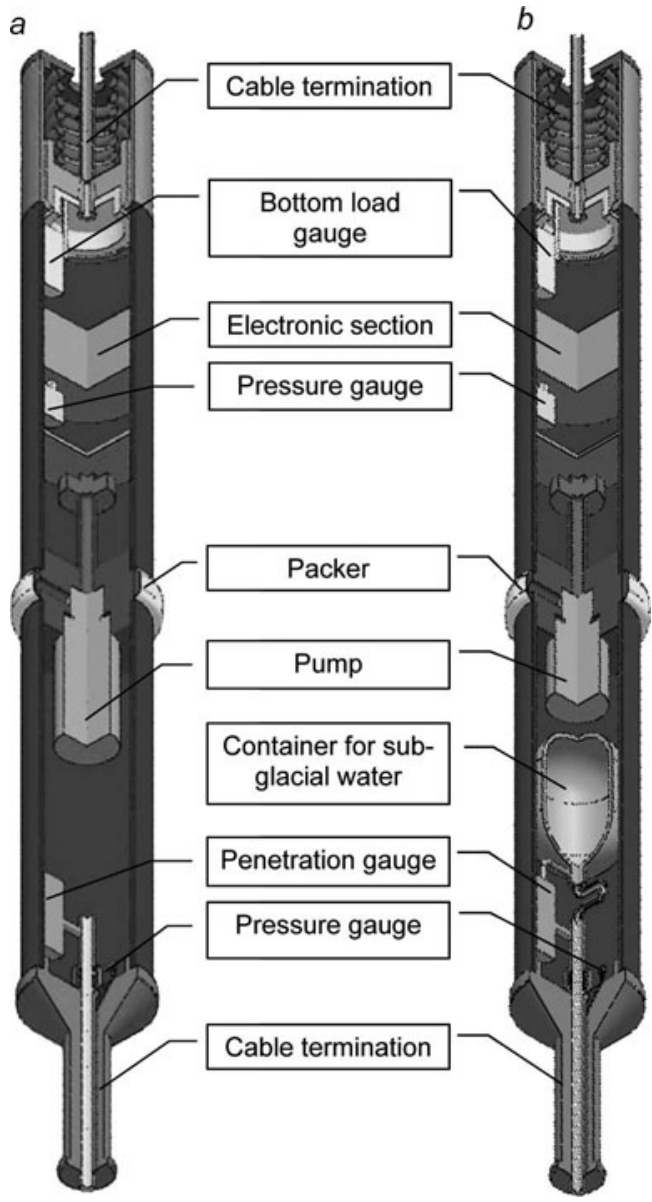

Fig. 24. Scheme of thermal drill TBPO-132: (a) without sampler; and (b) with sampler. 
thermal head touches the ice-water interface, a special penetration gauge gives a signal to the surface and the packer of the thermal drill is automatically turned on. The packer is needed for separation of the hole and lake at the instant of penetration.

If the special sterilized container is used, the valve is opened and the container is filled by subglacial water. When the container is full, the valve is closed. After estimating the actual difference between the pressures in the hole and in the lake and maintaining that pressure difference in the range 3-4 bar, the packer is turned off and the water from the lake is allowed to enter the hole (this moment is shown in Fig. 23, stage II). The thermal drill TBPO-132 will be pulled up. It should be possible to allow lake water to enter into the hole to a height of 30 or $40 \mathrm{~m}$ and to freeze.

The third and last stage will be conducted after confirming that the freezing in the hole is finished. Coring of the frozen lake ice can then be done with the electromechanical drill KEMS-135 down to 10-15 m above the icewater interface.

The project 'Basis and Design of an Environmentally Clean Penetration to Lake Vostok, Antarctica', prepared by SPSMI and AARI, was approved by the Ministry of Nature Resources of the Russian Federation (Order No. 257, 26 March 2001). The Russian project for the penetration to Vostok Subglacial Lake was presented to the 26th Antarctic Treaty Consultative Meeting in Madrid, Spain, in June 2003. The project for the penetration to Vostok Subglacial Lake has started. The distance between the hole bottom and the icelake interface is near $100 \mathrm{~m}$ now. In the 2006/07 summer season and the winter of 2007, additional drilling of the hole to a depth of near $3720 \mathrm{~m}$ is planned.

\section{ACKNOWLEDGEMENTS}

The report is dedicated to all 'miners' who tirelessly spent so many years and expended so much effort to further the cause of glaciology. From the very beginning, Vostok drilling was led by B.B. Kudryashov, who passed away on 12 April 2002. Since 1999, deep drilling at Vostok station has been carried out within the framework of the Federal Targeted Program (FTP) 'World Ocean', subprogram 'Antarctica', project 4 'Deep ice coring, paleoclimate research and Subglacial Lake Vostok exploration'. The authors thank H. Ueda for help in organizing and correcting material regarding the Vostok drilling. We also thank C.R. Bentley for very constructive and pertinent remarks and for editing this paper.

\section{REFERENCES}

Barkov, N.I. 1970. Predvaritel'nie rezul'taty bureniya lednikovogo pokrova na stantsii Vostok [Preliminary results of ice drilling at Vostok Station]. Inf. Byull. Sov. Antarkt. Eksped., 8(2), 58-60. [In Russian.]

Barkov, N.I., N.Ye. Bobin and G.K. Stepanov. 1973. Burenie skvazhiny v lednikovom pokrove Antarktidy na stantsii Vostok v $1970 \mathrm{~g}$ [Drilling on the ice sheet of Antarctica at Vostok Station in 1970]. Inf. Byull. Sov. Antarkt. Eksped., 8(7), 376-379. [In Russian.]

Chistyakov, V.K., A.M. Shkurko, A.A. Zemtsov, N.I. Vasiliev and S.P. Solov'ev. 1988. Eksperimental'niye burobie raboti na Severnoi Zemle v 1975-1985 gg [Experimental drilling operations at Severnaya Zemlya in 1975-1985]. In Geograficheskie i glyatsiologicheskie issledovaniya $v$ polarnikh stranakh
[Geographical and glaciological investigations in polar regions]. Leningrad, Gidrometroizdat, 33-42. [In Russian.]

Dmitriev, D.N., R.N. Vostretsov and I.A. Petukhov. 1978. Deformatsiya stenok glubokoy skvazhiny $v$ antarkticheskom lednikovom pokrove na stantsii Vostok [Deformation of the sides of a deep borehole in the Antarctic ice cover at Vostok Station]. Byull. Sov. Antarkt. Eksped., 98, 53-57. [In Russian.]

Dmitriev, A.N., V.M. Zubkov, A.V. Krasilev, N.G. Menshikov and V.M. Pashkevich. 1995. Rezul'taty burenia skvazhiny 5G na stantsii Vostok v $1991 \mathrm{~g}$ [Results of drilling hole 5G at Vostok Station in 1991]. Mater. Glyatsiol. Issled. 79, 174-176. [In Russian.]

Fisenko, V.F., N.E. Bobin, G.K. Stepanov, N.I. Slyusarev, G.N. Solov'ev and V.K. Chistyakov. 1974. Oslozhneniya i avarii pri glubokom burenii-protaivanii, ih likvidatsiya i preduprezhdenie [Complications and accidents during deep thermal-drilling, their removal and prevention]. Antarkt. Dokl. Kom. 13, 161-166. [In Russian.]

Fletcher, N.H. 1970. The chemical physics of ice. Cambridge, Cambridge University Press.

Ignatov, V.S. 1962. God na polyuse kholoda [A year on the pole of cold]. Moscow, Geografgiz. [In Russian.]

Korotkevich, Ye.S. and B.B. Kudryashov. 1976. Ice sheet drilling by Soviet Antarctic Expeditions. In Splettstoesser, J.F., ed. Ice-core drilling. Lincoln, NB, University of Nebraska Press, 63-70.

Kudryashov, B.B. 1989. Soviet experience of deep drilling in Antarctica. In International Symposium on Mining in the Arctic, 17-19 July 1989, Fairbanks, Alaska. Proceedings. Rotterdam, A.A. Balkema, 113-122.

Kudryashov, B.B. and A.M. Yakovlev. 1991. Drilling in the permafrost. Rotterdam, A.A. Balkema. (Russian Translation Series 84.)

Kudryashov, B.B., V.F. Fisenko, G.K. Stepanov and N.E. Bobin. 1973a. Opyt burenya ledyanogo pokrova Antarktidy [Experience of drilling in Antarctic Ice Sheet]. Antarkt. Dokl. Kom. 12, 145152. [In Russian.]

Kudryashov, B.B., N.Y. Bobin, N.I. Slyusarev, N.I. Stepanov, V.F. Fisenko and V.K. Chistyakov. 1973b. Teoriya i praktika bureniya-protaivaniya $\vee$ Antarktide [Theory and practice of thermal drilling in Antarctica]. Mater. Glyatsiol. Issled. 22, 7177. [In Russian with English summary.]

Kudryashov, B.B., V.K. Chistyakov and V.G. Vartykyan. 1975. Rezul'taty issledovanyi I razrabotok po glubokomu bureniyuprotaivaniyu vo I'dah Antarktidy [Investigation and designing results of deep drilling-melting in ice of Antarctica]. In Fysicheskie protsessy gornogo proizvodstva. Mezhvuzovsky sbornik, Vipusk 1 [Physical processes in mining. Inter-institution collection of articles, Issue 1]. Leningrad, Leningradskyi Gornyi Institut, 111-116. [In Russian.]

Kudryashov, B.B., V.K. Chistiakov and N.E. Bobin. 1977. Burenie skvazhin teplovim sposobom v lednikovom pokrove Antarktidy [Borehole thermodrilling in Antarctic ice sheet]. Moscow, VIEMS. [In Russian.]

Kudryashov, B.B., K.V. Chistyakov and V.A. Morev. 1983. Burenie lednikovogo pokrova Antarktidy teplovym sposobom [Thermal drilling in Antarctic ice sheet]. In 25 let Sovetskoi Antarkticheskoi Ekspeditsii [25th Anniversary of the Soviet Antarctic Expedition]. Leningrad, Gidrometeoizdat, 138-149. [In Russian.]

Kudryashov, B.B., K.V. Chistyakov, E.A. Zagrivny and V.Ya. Lipenkov. 1984a. Preliminary results of deep drilling at Vostok Station, Antarctica 1981-1982. CRREL Spec. Rep. 84-34, 123-124.

Kudryashov, B.B., V.K. Chistyakov and N.Y. Bobin. 1984b. Problema bureniya glubokikh skvazhin v tsentral'nykh rayonakh Antarktidy [Problem of drilling deep boreholes in the central regions of Antarctica]. Mater. Glyatsiol. Issled. 51, 168-172. [In Russian with English summary.]

Kudryashov, B.B., V.K. Chistyakov and V.S. Litvinenko. 1991. Burenie skvazhin $v$ usloviah izmenenia agregatnogo sostoyanya gornikh porod [Drilling in conditions of rock aggregate changes]. Leningrad, Nedra. [In Russian.] 
Kudryashov, B.B., N.I. Vasiliev, and P.G. Talalay. 1994. KEMS-112 electromechanical ice core drill. Mem. Natl. Inst. Polar Res., 49, Special Issue, 138-152.

Kudryashov, B.B., V.K. Chistyakov, N.I. Vasiliev and A.B. Volkov. 1998a. Burenie i issledovanie glubokoy skvazhiny na stantsii [Drilling and investigation of a deep hole at Vostok Station]. Antarkt. Dokl. Kom. 34, 73-78. [In Russian.]

Kudryashov, B.B. and 6 others. 1998b. Drilling equipment and technology for deep ice coring in Antarctica. In Hall, J., ed. Proceedings of Seventh Symposium on Antarctic Logistics and Operations, 6-7 August 1996, Cambridge, UK. Cambridge, British Antarctic Survey, 205-210.

Kudryashov, B.B., N.I. Vasiliev, V.M. Zubkov, A.V. Krasilev, V.V. Nikishin and V.K. Chistyakov. 2000. O burenii glubokoy skvazhiny na stantsii Vostok $v$ Antarktide [Drilling of the deep hole at Vostok Station in Antarctica]. In IV Mezhdunarodny Simposium po bureniyu skvazhin $v$ oslozhennikh usloviayh: Sbornik dokladov [Fourth International Symposium on Drilling under Complicated Conditions: Collection of Reports]. St Petersburg, SPSMI, 7-11. [In Russian.]

Kudryashov, B.B. and 9 others. 2002. Deep ice coring at Vostok Station (East Antarctica) by an electromechanical drill. Mem. Natl. Inst. Polar Res., 56, Special Issue, 91-102.

Lipenkov, V.Ya. and N.I. Barkov. 1998. Stroyeniye Antarkticheskogo lednikovogo pokrova po rezul'tatam glubokogo bureniya na stantsii Vostok [Internal structure of the Antarctic ice sheet as revealed by deep core drilling at Vostok station]. In Izuchenie ozera Vostok - nauchnye zadactu i tekhnologii. Mezhdunarodnoe soveschanie. Tezisy dokladov. [Lake Vostok study: scientific objectives and technological requirements. International workshop. Abstracts]. St Petersburg, Arctic and Antarctic Research Institute, 31-35. [In Russian.]

Lipenkov, V.Y., N.I. Barkov and A.N. Salamatin. 2000. Istoriya klimata i oledeneniya Antarktidy po rezul'tatam izucheniya ledanogo kerna so stantsii Vostok [The history of climate and glaciation of Antarctica from results of the ice core study at Vostok Station]. Probl. Arkt. Antarkt., 72, 197-236. [In Russian with English summary.]
Ridley, J.K., W. Cudlip and S.W. Laxon. 1993. Identification of subglacial lakes using ERS-1 radar altimeter. J. Glaciol., 39(133), 625-634.

Tchistiakov, V.K., A. Kracilev, V.Y. Lipenkov, J.P. Balestrieri, C. Rado and J.R. Petit. 1994. Behaviour of a deep hole drilled in ice at Vostok station. Mem. Nat. Inst. Polar Res., 49, Special Issue, 247-255.

Vartykyan, V.G., V.I. Kovalenko and B.S. Moiseev. 1977. Opyt iskrivleniya skvazhin $v$ usloviyah Antarktidy [Experience of borehole deviation in Antarctica]. Inf. Byull. Sov. Antarkt. Eksped., 96, 24-25. [In Russian.]

Vasil'yev, N.I., B.B. Kudryashov, P.G. Talalay and V.K. Chistyakov. 1993. Core drilling by electromechanical drill. Polar Rec., 29(170), 235-237.

Verkulich, S.R. and 11 others. 2002. Proposal for penetration and exploration of subglacial Lake Vostok, Antarctica. Mem. Natl. Inst. Polar Res., 56, Special Issue, 245-252.

Zagrivny, E.A. and B.S. Moiseev. 1988. Oslozhneniya i metody ih ustraneniya pri burenii glubokoi skvazhiny na stantsii Vostok [Complications and methods of their removal during deep drilling at Vostok station]. Zapiski Leningrad. Gorn. Inst., 116, 87-93.

Zagrivny, E.A., A.A. Zemtsov, R.N. Vostretsov and A.M. Shkurko. 1980. Eksperimental'noe burenie skvazhiny, zalitoi nezamerzayushchei zhidkost'yu [Experimental drilling of a hole filled by a non-freezing liquid]. Inf. Byull. Sov. Antarkt. Eksped., 100, 119-123. [In Russian.]

Zagrivny, E.A., A.A. Zemtsov, Yu.B. Kononov, B.S. Moiseev, P.A. Petukhov and A.M. Shkurko. 1981. Opyt byreniyaplavleniya skvazhin, zalitkh nezamerzayushchey zhidkostyu, $v$ Antarktike i Arktike [Experience of drilling by melting of holes filled with a non-freezing liquid in Antarctica and the Arctic]. Zapiski Leningrad. Gorn. Inst., 86, 79-83. [In Russian.]

Zagrivny, E.A., B.S. Moiseev and A.M. Shkurko. 1985. Rezul'taty polevih ispytanyi vysokochastotnogo termoburovogo komplekska TBS-112VCh pri burenyi glubokoi skvazhiny v nizkotemperaturnom lednikovom pokrove (stantsiya Vostok) [Results of field tests of a high frequency thermal drill TBS-112VCh by drilling a deep hole in a low-temperature ice sheet (Vostok station)]. Zapiski Leningrad. Gorn. Inst., 105, 103-107. [In Russian.] 